\title{
Synoptic forcing of wave states in the southeast Chukchi Sea, Alaska, at nearshore locations
}

\author{
Oceana P. Francis • David E. Atkinson
}

Received: 18 October 2011/Accepted: 11 March 2012/Published online: 25 March 2012

(C) The Author(s) 2012. This article is published with open access at Springerlink.com

\begin{abstract}
Two bottom-mounted recording Doppler current profilers (RDCP) were deployed at nearshore locations (approximately 3 and $8 \mathrm{~km}$ offshore, in about $18 \mathrm{~m}$ water depth) in the southeast Chukchi Sea, Alaska, from October 2009 to September 2010 (UTC) with the goal of linking observed wave activity - wind-sea and swells - to their synoptic drivers. The northerly RDCP recorded a total of 16 events of elevated wave states: 15 exceeding $1 \mathrm{~m}$ significant wave height (SWH), and 1 exceeding $2 \mathrm{~m} \mathrm{SWH}$. The southerly RDCP recorded a total of 25 events of elevated wave states: 23 exceeding $1 \mathrm{~m} \mathrm{SWH}, 2 \mathrm{~m}$ exceeded on two occasions and a SWH of $3 \mathrm{~m}$ was observed. Detailed analysis of the three large events (i.e., SWH events $\geq 2 \mathrm{~m}$ ), including comparison with high-resolution reanalysis wind data (North America regional reanalysis), strongly suggested the wave energy evolved from a distant storm and would be defined as swell. Due to the close proximity of the shoreline to the east of the instruments, wind speeds based on reanalysis were constrained so fetch was westerly. Wave direction was also westerly, varying about $25^{\circ}$ to the north (clockwise) or the south (counterclockwise) from the wind direction which is believed to be influenced by fetch and the strong current flow located where the nearshore RDCPs were deployed. Shore-fast sea ice is also believed to play a role but shown to only dampen wave activity for 3 months (January-April 2010), thus implying early ice breakup in this nearshore region. Two events appeared to be driven by southwesterly winds associated with cyclonic systems that moved into the eastern Chukchi Sea and then stalled. However, the second storm event appeared to be driven by northwesterly winds associated with a cyclonic system over the Brooks Range, a less common occurrence. Given that the typical storm activity in the region occurs as storms move into the Bering Sea in fall, this
\end{abstract}

O. P. Francis $(\bowtie) \cdot$ D. E. Atkinson

Department of Atmospheric Sciences, International Arctic Research Center,

University of Alaska Fairbanks, 903 Koyukuk Drive, PO Box 757340, Fairbanks, AK 99775, USA

e-mail: oceana@iarc.uaf.edu

D. E. Atkinson

e-mail: datkinso@uvic.ca

Present Address:

D. E. Atkinson

Department of Geography, University of Victoria, Victoria, BC, Canada 
represents another potential source for wave conditions posing danger to people on the water or to coastal infrastructure.

Keywords Swell · Wind · Nearshore - Recording Doppler current profiler ·

Chukchi Sea $\cdot$ Delong mountain terminal

\section{Introduction}

Francis and Atkinson (2012) presented an analysis of the highest significant wave height (SWH) events of duration $\geq 6 \mathrm{~h}$ for the period July-December 2007 at an offshore location. Their analyses placed the recorded wave data in the context of the evolving meteorological condition at the synoptic and mesoscale levels. The synoptic-scale included evaluating large cyclonic systems in the Bering Sea. The mesoscale involved evaluating high winds events at the edge of these cyclones, or bordering high and low pressures.

This companion paper also analyzes waves within a meteorological context, but does so for 2010 and at two nearshore locations. In particular, proximity to the coast is expected to dampen both wind and wave activity compared with an offshore location, as will be shown in this paper. For a complete background, the reader should refer to the Introduction and Background sections in Francis and Atkinson (2012).

As mentioned in Francis and Atkinson (2012), a major industrial stakeholder in this area is Teck Alaska Inc., who operates the Delong Mountain Terminal. This facility has experienced periods when waves have caused shutdowns due either to direct impact on the terminal infrastructure or to set up of dangerous conditions for handling the large freighters, which given their length (up to $300 \mathrm{~m}$ ), can be especially susceptible to long-period swell energy at or near the resonance of the vessel. In particular, these nearshore gauge deployments have specific relevance for the Teck operations. Freighters do not berth at a dock but are positioned for loading 3-6 km offshore, where the newly deployed recording Doppler current profilers were positioned. Therefore, using an observational wave data set from recording Doppler current profilers (RDCP), this paper focuses on the occurrence of waves and their synoptic drivers in the SE Chukchi Sea. Of particular interest is the identification of atmospheric forcing functions defining wind-seas and swell wave conditions.

The primary objective of this study is to identify and characterize the synoptic patterns that drive observed occurrences of SWH events in the southeast Chukchi Sea. A secondary objective is to distinguish between the occurrence of swell and wind-sea in a nearshore region. A third objective is to assess the extent to which wind data extracted from a widely used, high-resolution reanalysis data set (NCEP North America regional reanalysis) is correlated to the observed RDCP wave data set and thus examine its suitability for longerterm modeling of wave forecasting and hindcasting in this region. This is performed evaluating how wind speed and direction vary with wave height and direction on time series and spectral plots. Although it is known that reanalysis winds tend to underestimate peak storm wind speeds, especially the coarse resolution global reanalyses, what this means specifically for reproducing waves in the southeast Chukchi is not precisely known. These tasks will utilize observational data acquired from recording Doppler current profilers (RDCP) placed in the southeast Chukchi Sea in 2009-2010. Estimates of observed SWH event occurrences will be generated using data from the 32-km resolution "North American regional reanalysis (NARR)" atmospheric data set (Mesinger et al. 2006) and the NCEP/DOE Global Reanalysis 2 (Kistler et al. 2001). It is hypothesized that, in the SE Chukchi Sea study area, the primary wave direction nearshore is from the northwest 
because that is the direction of greatest fetch that allows waves to propagate across the Chukchi Sea. These factors are elaborated upon below.

The present paper has one additional goal: to compare data from two RDCPs deployed concurrently in 2009-2010 and separated by $53 \mathrm{~km}$. Francis and Atkinson (2012) examined RDCP data collected in $34 \mathrm{~m}$ water depth approximately $82 \mathrm{~km}$ north of the nearest coastline (Seward Peninsula, Alaska) in the offshore Chukchi Sea in 2007. In this paper, the two RDCPs were within 3.5 and $10.8 \mathrm{~km}$ off the western Alaskan coast, and in water depths of 17 and $18 \mathrm{~m}$, respectively. The results provide the opportunity to compare similarities and differences in wave conditions for the deployment in the SE Chukchi Sea.

The organization of the paper consists of an overview of the regional atmospheric setting and instrumentation background, a results section containing description of major observed wave events with detailed analysis and intermediate conclusions. Broader conclusions and discussion are reserved for the conclusions section. Wave events were analyzed as they were described, for a more efficient presentation.

\section{Methods and data}

For this paper, wind and wave direction use the same convention. Wind direction is defined as the direction from which the wind is coming and is given in degrees true bearing. Current direction is defined as the direction to which the current flow is going toward in degrees true bearing. The true bearing to a point is the angle measured in degrees in a clockwise direction from the north line.

\subsection{Atmospheric datasets}

Atmospheric parameters were obtained from the NARR data set (Mesinger et al. 2006). This gridded data of $0.3^{\circ}$ and $1^{\circ}$ resolution are taken from model runs which assimilate point source and scatterometer data into a weather forecast model. This system, a "reanalysis" data set, was developed and is maintained by the National Centers for Environmental Prediction (NCEP) of the US national oceanic and atmospheric administration (NOAA). For this project, three parameters were extracted from the NARR data set-geopotential height at $925 \mathrm{hPa}$, vector wind at $925 \mathrm{hPa}$, and vector wind at $10 \mathrm{~m}$. Storm center, position, and tracking were evaluated using geopotential height at $925 \mathrm{hPa}$ and vector wind at $925 \mathrm{hPa}$. Local winds were evaluated using vector wind at $10 \mathrm{~m}$ and extracted as time series from the NARR grid point nearest to the RDCP instrument location (see Fig. 1 for NARR grid point locations). Mean sea level pressure data, drawn from the NCEP/National Center for Atmosphere Research Global Reanalysis data set (Kistler et al. 2001), were also used for this analysis.

\subsection{RDCP instrument deployment and wave parameters}

The overall project entailed three data-gathering efforts using RDCP (recording Doppler current profiler) deployments. One RDCP was deployed to an open water location during the ice-free period, July-December 2007 UTC ("2007” in Fig. 1), discussed in Francis and Atkinson (2012), and two RDCPs were later deployed to coastal locations during ice-free and ice-covered periods October 2009-September 2010 UTC ("2009N" and "2009S" in Fig. 1), discussed in this paper. Station 2007 was located $82 \mathrm{~km}$ north of the Seward Peninsula, Alaska, in a water depth of $34 \mathrm{~m}$. Station $2009 \mathrm{~N}$ was located $3.5 \mathrm{~km}$ off the western Alaskan 


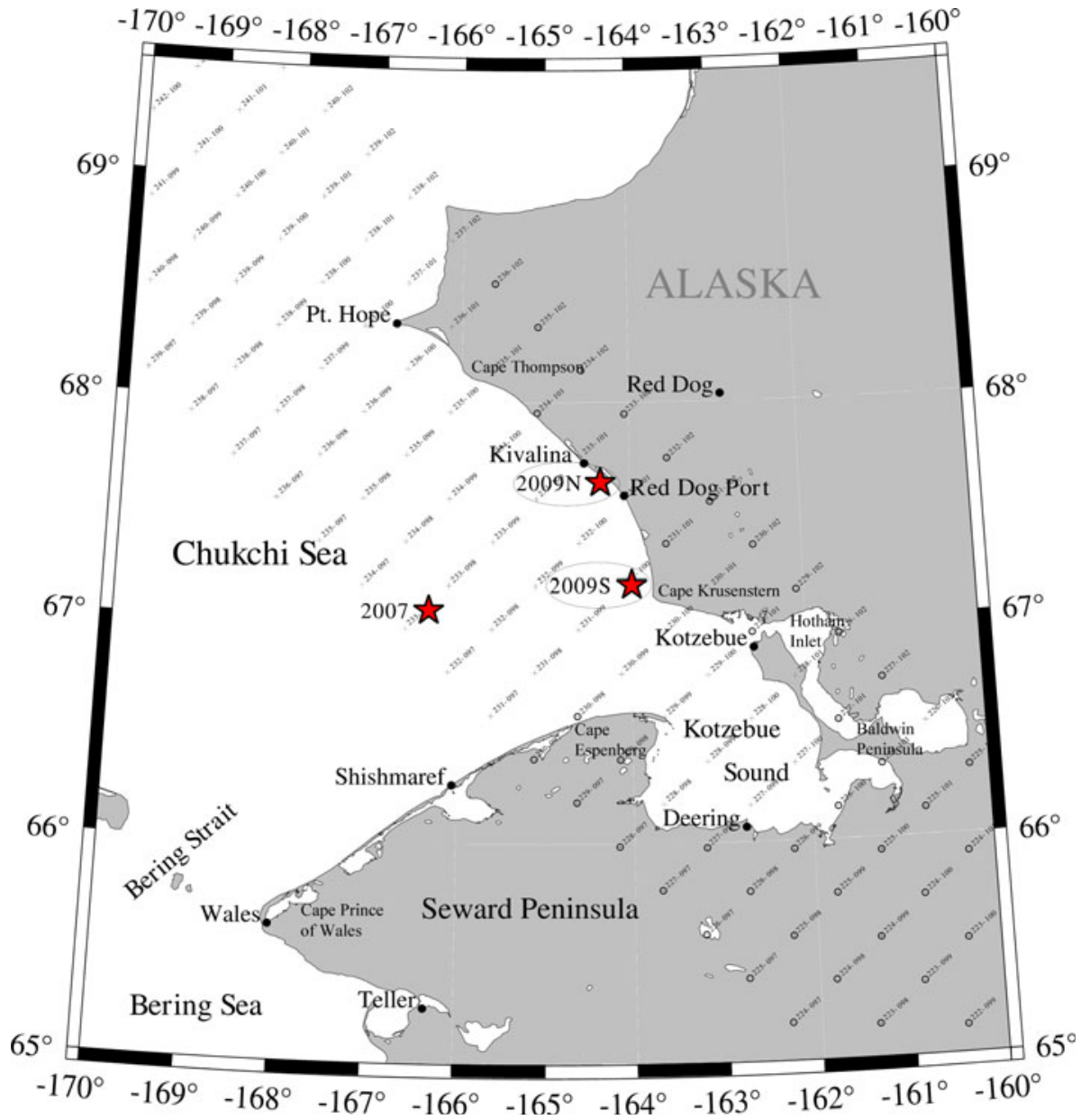

Fig. 1 In situ measurement locations in the Chukchi Sea. Geographical map of south-eastern Chukchi Sea showing location of North American regional reanalysis (NARR) $10 \mathrm{~m}$ winds (small print-for location purposes only) and the three recording Doppler current profiler (RDCP) Stations 2009N and 2009S (mentioned in this paper for the nearshore- "circled stars") and Station 2007 (mentioned in Francis and Atkinson (2012), offshore-star)

coast in a water depth of $17 \mathrm{~m}$. Station 2009S was located $10.8 \mathrm{~km}$ off the western Alaskan coast in a water depth of $18 \mathrm{~m}$.

The bottom-positioned RDCP (AADI 2006), by analyzing Doppler shifts of acoustic returns, recorded a number of wave observations denoted here as $N$. The frequency of the RDCP is $2 \mathrm{~Hz}$. Each N observation lasts $15 \mathrm{~min}$ where the RDCP awakens every $1.5 \mathrm{~h}$ (for 2007 it was every $2 \mathrm{~h}$ ) and records for $15 \mathrm{~min}$ sampling at $2 \mathrm{~Hz}$ which provides $i=1,800$ samples for each $\mathrm{N}$ observation.

Station $2009 \mathrm{~N}$ recorded every $1.5 \mathrm{~h}$ for $8,041 \mathrm{~h}$ and $15 \mathrm{~min}$, for $N=4,596$. Station 2009S recorded every $1.5 \mathrm{~h}$ for $8,204 \mathrm{~h}$, for $N=4689$. Each observation $i$ includes wave height $H_{i}$, wave period $T_{i}$, and wave direction $D_{i}$. From these parameters, the RDCP estimates the following: $\mathrm{SWH}, H_{m 0}$, mean wave period, $T_{m 01}$, mean zero crossing, $T_{m 02}$ or 
$\bar{T}_{z}$, Energy wave direction, $D_{E}$, Mean direction, $D_{m}$, and Peak direction, $D_{p}$. For this study, significant wave height, $H_{m 0}$, mean zero crossing, $T_{m 02}$, and mean wave direction, $D_{m}$, were retained for analysis. The mean zero crossing parameter, $T_{m 02}$, is the time obtained by dividing the record length by the number of downcrossings (or upcrossings) in the record (AADI 2006), compared with the mean wave period, $T_{m 01}$, which is the wave period corresponding to the mean frequency of the spectrum (WMO 1998).

Wave spectra were estimated using the maximum likelihood method (MLM). Upper cutoff frequency was $0.6 \mathrm{~Hz}$. Fast Fourier transform (FFT) size was 128.

\subsection{Wave event and atmospheric analysis}

A SWH event was defined using approaches outlined in Hudak and Young (2002) and Francis-Chythlook (2004); that is, the wave magnitude exceeds and remains over a given threshold for a period of $6 \mathrm{~h}$ or more in duration. Two threshold set-points were established: 1, 2 m (for 2007-three threshold set-points were established: 1, 2, $3 \mathrm{~m}$ ). The SWH event was considered to have ended when the wave magnitude dropped below the threshold for $6 \mathrm{~h}$ or more.

Spatial plots of pressure and winds were manually examined to assess the atmospheric state at the time of identified SWH events. The atmospheric progenitor typically was a "storm" as defined by the presentation of a closed low feature on a $925 \mathrm{hPa}$. However, persistent patterns characterized by strong pressure gradients that were not storms in motion are not uncommon in this region. The $925 \mathrm{hPa}$ level was chosen to minimize interference from surface conditions yet provide a level low enough to adequately represent surface pressure conditions.

\section{Station 2009N and 2009S analysis and results}

\subsection{Station $2009 \mathrm{~N}$ and 2009S overview}

At Station 2009N, during the October 2009-September 2010 UTC recording period, seventeen SWH events were identified: sixteen $1 \mathrm{~m}$, and one $2 \mathrm{~m}$. The longest duration events $(1 \mathrm{~m})$ occurred during mid-July to mid-August. The large magnitude events $(2 \mathrm{~m}$ event) of longest duration occurred in mid-July. At Station 2009S, during the October 2009-September 2010 UTC recording period, twenty-seven (SWH) events were identified: twenty-five $1 \mathrm{~m}$ and two $2 \mathrm{~m}$. The longest duration events $(1 \mathrm{~m})$ occurred during mid-July to mid-August, and also in mid-October. The longest duration/large magnitude events $(2 \mathrm{~m}$ events) occurred in mid-July and mid-August.

Sea surface temperature (SST), monitored by Station 2009 N, dropped and remained below $0{ }^{\circ} \mathrm{C}$ starting November 9, 2009 to July 2, 2010. SST, monitored by Station 2009S, dropped and remained below $0{ }^{\circ} \mathrm{C}$ starting November 11, 2009 to July 1, 2010. SST is important since wave action is dampened by first-year sea ice that forms when freeze-up occurs, so being able to identify when SST remains below $0{ }^{\circ} \mathrm{C}$ (i.e., freeze-up) helps to identify variability of SWH events throughout the 11-month wave record. Therefore, these freeze-up periods indicate the generation of ice coverage (shore-fast ice) at the free surface, and a substantial reduction in the wave climate. For the 11-month wave record of Stations 2009N and 2009S, the main events (SE3, SE4, SE5) occurred during a 1-month time frame 
(i.e., mid-July through mid-August). This was shortly after SST warmed to above $0{ }^{\circ} \mathrm{C}$, and not later in the year as seen in the offshore region in 2007 Francis and Atkinson (2012).

The SWH $\left(H_{m 0}\right)($ Fig. 2) for October 2009 to September 2010 encompasses the entire RDCP Station $2009 \mathrm{~N}$ wave record. SST, monitored by Station 2009N, dropped and remained below $0{ }^{\circ} \mathrm{C}$ starting November 9, 2009 to July 2, 2010. However, SWHs between 1.0 and $2.0 \mathrm{~m}$ was seen during November 2009 to January 2010, and also during June to July 2010. The highest SWHs during November 2009 to July 2010 between 1.5 and $2.0 \mathrm{~m}$ were observed during December 2009, and April to June 2010. The period of minimal wave activity (i.e., SWHs $<0.5 \mathrm{~m}$ ) occurred during January to April 2010. This wave activity (i.e., SWH $>1.5 \mathrm{~m}$ ) that began in mid-April 2010 implies breakup of sea ice began very early in the season at Station 2009 N. Therefore, breakup for shore-fast sea ice began at an earlier period (mid-April 2010) than what the RDCP SST implies (early July 2010).

The NARR 10-m wind speed (Fig. 3) also for October 2009 to September 2010 does not correlate with the SWHs $<1 \mathrm{~m}$ (Fig. 2). Only with wind speeds $>6 \mathrm{~ms}^{-1}$ was there some correlation with wave activity (Figs. 2, 3), although the wind and wave directions differed by $10^{\circ}-25^{\circ}$ (Figs. 4 and 5). Although the waves may have been somewhat wind driven, there was probably an external factor act work such as current flow and shoreline bathymetry.

The RDCP mean wave direction $\left(D_{m}\right)$ (Fig. 4) at Station $2009 \mathrm{~N}$ for October 2009September 2010 is shown. From November 2009 to June 2010, the wave direction is shown to arrive from all directions. However, this was during a freeze-up period, so sea ice cover would dominate the region during this time (i.e., November 2009-June 2010). The sea ice cover would dampen wind-wave interaction, so waves would be more affected by currents and swell. These ice-covered waves generally had SWHs $\leq 0.5 \mathrm{~m}$, with the exception of SWHs between 1 and $2 \mathrm{~m}$ (Fig. 2) during the months of December, January, April, and June. Francis and Atkinson (2012) found that December cyclones coincided with considerable SWH (i.e., 1.5-2.5 m) at an offshore location (Station 2007). This also agrees with the fact that the strongest extra-tropical cyclones are most likely to form in December and January (Sienkiewicz et al. 2005). During October to November 2009 (before freeze-up),

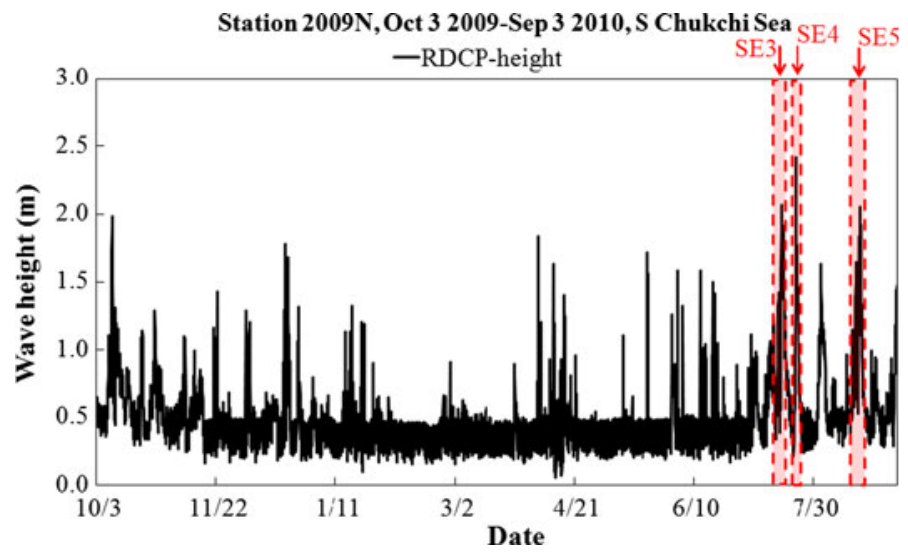

Fig. 2 Station 2009N significant wave height. Recording Doppler current profiler (RDCP) significant wave height (SWH) at Station 2009N for entire RDCP wave record October 3, 2009-September 3, 2010. Station location and depth are $67^{\circ} 38^{\prime} 17.76^{\prime \prime} \mathrm{N}, 164^{\circ} 20^{\prime} 46.26^{\prime \prime} \mathrm{W}$ (near Kivalina, AK), and $17 \mathrm{~m}$, respectively 


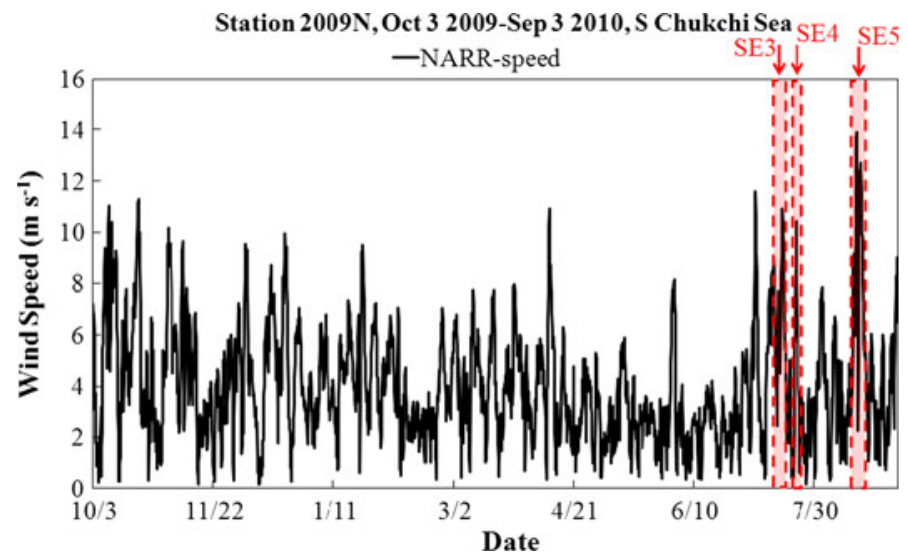

Fig. 3 Station $2009 \mathrm{~N}$ wind speed. North American regional reanalysis (NARR) $10 \mathrm{~m}$ wind speed at Station 2009N for entire recording Doppler current profiler (RDCP) wave record October 3, 2009-September 3, 2010. Station location and depth are $67^{\circ} 38^{\prime} 17.76^{\prime \prime} \mathrm{N}, 164^{\circ} 20^{\prime} 46.26^{\prime \prime} \mathrm{W}$ (near Kivalina, AK), and $17 \mathrm{~m}$, respectively

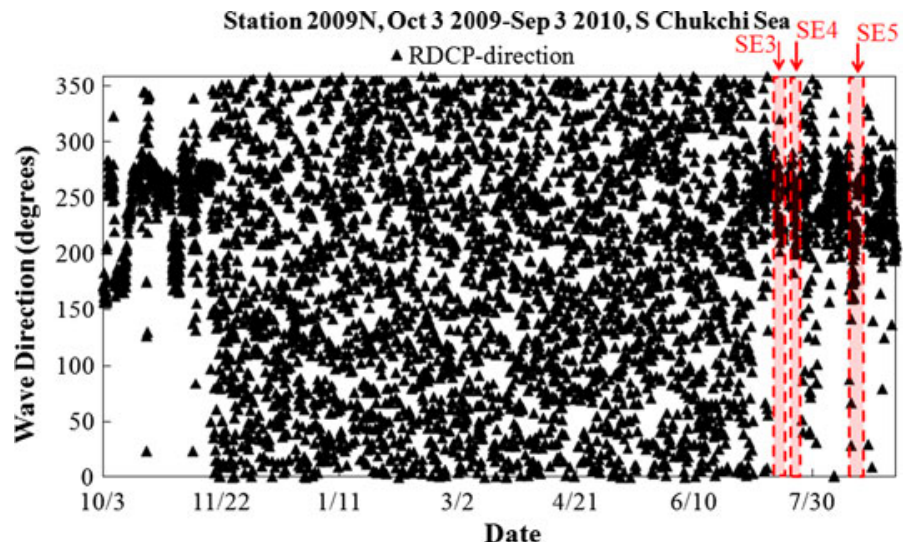

Fig. 4 Station 2009N wave direction. Recording Doppler current profiler (RDCP) wave direction at Station $2009 \mathrm{~N}$ for entire RDCP wave record October 3, 2009-September 3, 2010. Station location and depth are $67^{\circ} 38^{\prime} 17.76^{\prime \prime} \mathrm{N}, 164^{\circ} 20^{\prime} 46.26^{\prime \prime} \mathrm{W}$ (near Kivalina, AK), and $17 \mathrm{~m}$, respectively

and July to September 2010 (after freeze-up), the wave direction was shown to be mainly westerly where most of the highest SWH (i.e., 1-2.5 m) activity occurred.

The NARR 10-m wind direction (Fig. 5) was not correlated with the wave direction (Fig. 4). The wind direction displayed mainly northerly and easterly directions during October 2009-September 2010 (Fig. 5). For the highest SWHs (i.e., SWHs occurring before and after freeze-up), the wind direction was southerly, westerly, and northerly. This is consistent with the notion that easterly wind directions do not affect wave states since the shoreline is only several kilometers to the east, limiting available fetch needed to generate easterly waves.

The SWH (Fig. 6) for October 2009-September 2010 encompasses the entire RDCP Station 2009S wave record. SST, monitored by Station 2009S, dropped and remained 


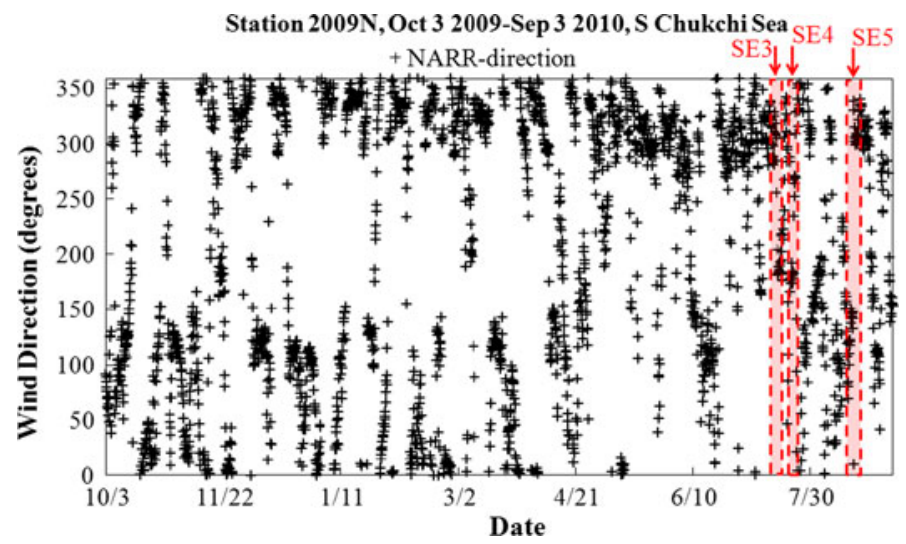

Fig. 5 Station $2009 \mathrm{~N}$ wind direction. North American regional reanalysis (NARR) $10 \mathrm{~m}$ wind direction at Station 2009N for entire recording Doppler current profiler (RDCP) wave record October 3, 2009September 3, 2010. Station location and depth are $67^{\circ} 38^{\prime} 17.76^{\prime \prime} \mathrm{N}, 164^{\circ} 20^{\prime} 46.26^{\prime \prime} \mathrm{W}$ (near Kivalina, AK), and $17 \mathrm{~m}$, respectively

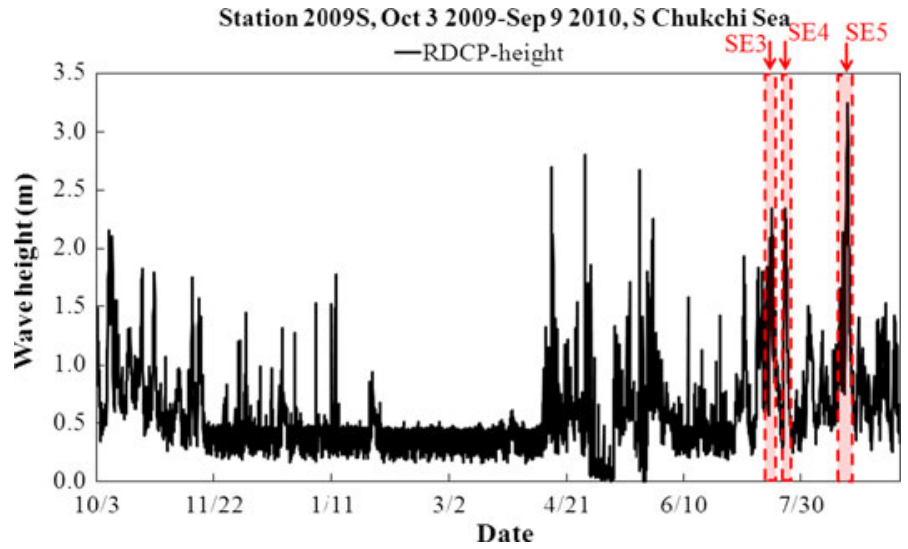

Fig. 6 Station 2009S significant wave height. Recording Doppler current profiler (RDCP) significant wave height (SWH) at Station 2009N for entire RDCP wave record October 3, 2009-September 9, 2010. Station location and depth are $67^{\circ} 10^{\prime} 33.30^{\prime \prime} \mathrm{N}, 163^{\circ} 59^{\prime} 23.94^{\prime \prime} \mathrm{W}$ (near Cape Krusenstern, AK), and $18 \mathrm{~m}$, respectively

below $0{ }^{\circ} \mathrm{C}$ starting November 11, 2009 to July 1, 2010. However, SWH activity of 1.0-2.0 m was seen during November 2009-January 2010, and also during June-July 2010. Also, uncharacteristically high SWHs $>2.5 \mathrm{~m}$ were observed during April-May 2010, which followed a long period (January-April 2010) of virtually no wave activity (i.e., SWHs $<0.5 \mathrm{~m}$ ). This wave activity implies breakup of sea ice began very early in the season (i.e., mid-April 2010) at Station 2009S implying earlier periods for breakup of shore-fast sea ice.

The NARR 10-m wind speed (Fig. 7) for October 2009-September 2010 also shows similar characteristics of wave-wind relationships as shown for Station 2009N (Figs. 2, 3) where wind and wave directions differed by $10^{\circ}-25^{\circ}$ (Figs. 8 and 9). Similar to Station 
$2009 \mathrm{~N}$, it is also thought that waves may have been somewhat wind driven, but that there was an external factor at work such as current flow and shoreline bathymetry.

The RDCP mean wave direction (Fig. 8) and the NARR 10-m wind direction (Fig. 9) at Station 2009S for October 2009-September 2010 are shown. Again, the wind and wave directions for Station 2009S (Figs. 8, 9) are very similar to Station 2009N (Figs. 4, 5) where wind direction (Fig. 9) is uncorrelated with wave direction (Fig. 8). It was concluded that wave states were affected by sea ice cover during almost the same period as Station $2009 \mathrm{~N}$ and were additionally affected by shoreline and the current flow.

The results shown in Tables 1 and 2 refer to the wave and wind conditions when the significant wave height $\geq 1 \mathrm{~m}$ during a particular "event" - where an "event" is described in Sect. 2.3. The three largest SWH events, i.e., $\geq 2 \mathrm{~m}$, are examined below in detail: event

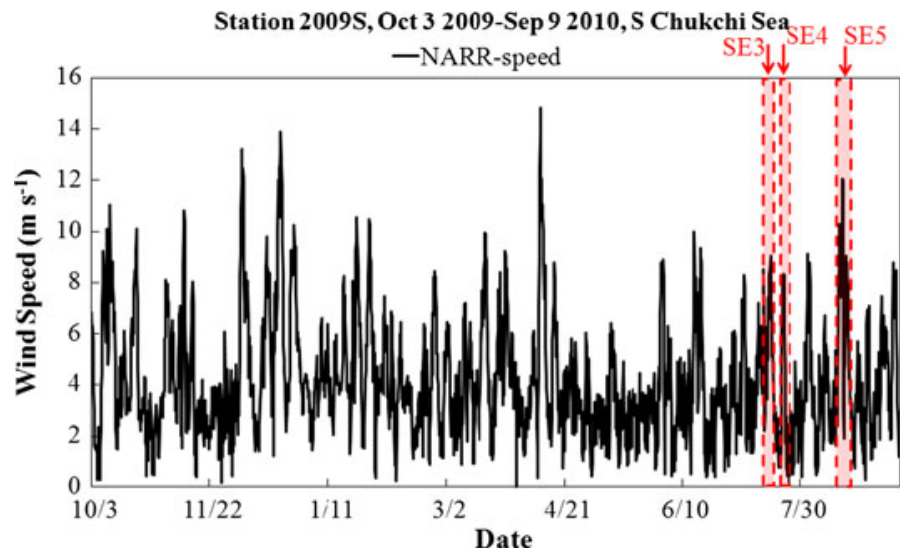

Fig. 7 Station 2009S wind speed. North American regional reanalysis (NARR) $10 \mathrm{~m}$ wind speed at Station 2009S for entire recording Doppler current profiler (RDCP) wave record October 3,2009-September 9, 2010. Station location and depth are $67^{\circ} 10^{\prime} 33.30^{\prime \prime} \mathrm{N}, 163^{\circ} 59^{\prime} 23.94^{\prime \prime} \mathrm{W}$ (near Cape Krusenstern, AK), and $18 \mathrm{~m}$, respectively

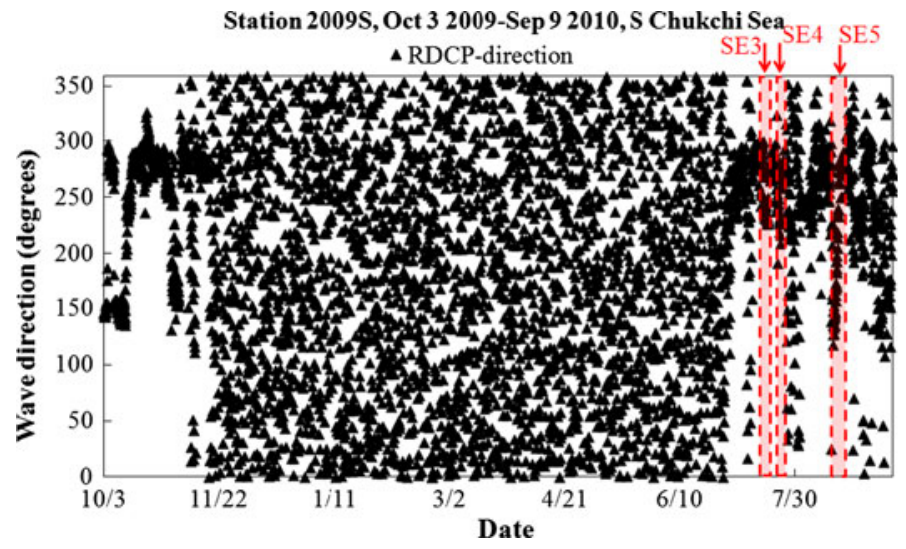

Fig. 8 Station 2009S wave direction. Recording Doppler current profiler (RDCP) wave direction at Station 2009N for entire RDCP wave record October 3, 2009-September 9, 2010. Station location and depth are $67^{\circ} 10^{\prime} 33.30^{\prime \prime} \mathrm{N}, 163^{\circ} 59^{\prime} 23.94^{\prime \prime} \mathrm{W}$ (near Cape Krusenstern, AK), and $18 \mathrm{~m}$, respectively 


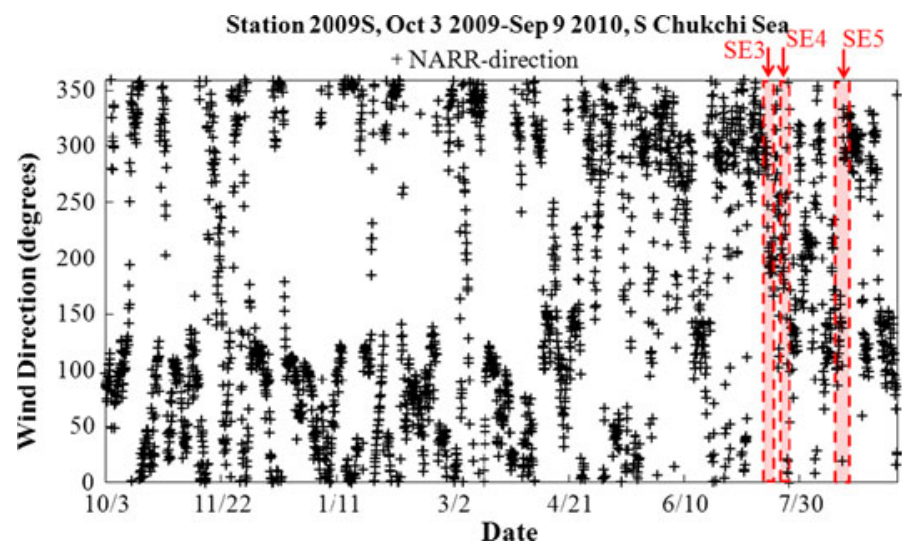

Fig. 9 Station 2009S wind direction. North American regional reanalysis (NARR) $10 \mathrm{~m}$ wind direction at Station $2009 \mathrm{~N}$ for entire recording Doppler current profiler (RDCP) wave record October 3, 2009September 9, 2010. Station location and depth are $67^{\circ} 10^{\prime} 33.30^{\prime \prime} \mathrm{N}, 163^{\circ} 59^{\prime} 23.94^{\prime \prime} \mathrm{W}$ (near Cape Krusenstern, AK), and $18 \mathrm{~m}$, respectively

Table 1 Station $2009 \mathrm{~N}$ significant wave height events $\geq 1 \mathrm{~m}$

\begin{tabular}{|c|c|c|c|c|c|c|c|}
\hline SWH event & Date & $\begin{array}{l}\text { SWH } \\
\text { duration (h) }\end{array}$ & $\begin{array}{l}\mathrm{Hm0} \\
(\mathrm{m})\end{array}$ & $\begin{array}{l}\mathrm{Tm} 02 \\
\text { (s) }\end{array}$ & $\begin{array}{l}\text { Wave } \\
\operatorname{dir}\left(^{\circ}\right)\end{array}$ & $\begin{array}{l}\text { Wind } \\
\text { spd }(\mathrm{m} / \mathrm{s})\end{array}$ & $\begin{array}{l}\text { Wind } \\
\operatorname{dir}\left({ }^{\circ}\right)\end{array}$ \\
\hline 2009 N-1m-1 & $10 / 9-10 / 10 / 2009$ & 17.5 & 1.5 & 4.3 & 170 & 7.8 & 122 \\
\hline $2009 \mathrm{~N}-1 \mathrm{~m}-2$ & $10 / 11-10 / 11 / 2009$ & 17.5 & 1.1 & 3.8 & 180 & 8.4 & 114 \\
\hline $2009 N-1 m-3$ & $10 / 22-10 / 22 / 2009$ & 7 & 1.1 & 3.5 & 285 & 9.9 & 16 \\
\hline $2009 N-1 m-4$ & $10 / 27-10 / 27 / 2009$ & 8.75 & 1.1 & 4.2 & 264 & 6.2 & 347 \\
\hline $2009 N-1 m-5$ & $11 / 9-11 / 9 / 2009$ & 7 & 1.0 & 3.4 & 251 & 9.1 & 137 \\
\hline 2009 N-1m-6 & $12 / 6-12 / 6 / 2009$ & 7 & 1.1 & 4.1 & 140 & 8.8 & 125 \\
\hline 2009 N-1m-7 & $12 / 21-12 / 22 / 2009$ & 21 & 1.2 & 3.9 & 130 & 9.1 & 114 \\
\hline 2009 N-1m-8 & $5 / 21-5 / 22 / 2010$ & 10.5 & 1.4 & 5.4 & 177 & 2.3 & 299 \\
\hline $2009 N-1 m-9$ & $7 / 12-7 / 13 / 2010$ & 8.75 & 1.1 & 3.8 & 274 & 8.5 & 317 \\
\hline $2009 \mathrm{~N}-1 \mathrm{~m}-10$ & $7 / 14-7 / 15 / 2010$ & 12.25 & 1.3 & 3.9 & 272 & 6.8 & 314 \\
\hline $2009 \mathrm{~N}-1 \mathrm{~m}-11$ & $7 / 16-7 / 18 / 2010$ & 50.75 & 1.5 & 4.8 & 230 & 8.0 & 191 \\
\hline $2009 N-2 m-12^{\mathrm{a}}$ & $7 / 22-7 / 23 / 2010$ & 38.5 & 1.6 & 5.0 & 234 & 6.5 & 225 \\
\hline 2009 N-1m-13 & $8 / 1-8 / 3 / 2010$ & 52.5 & 1.2 & 4.4 & 235 & 6.0 & 180 \\
\hline 2009 N-1m-14 & $8 / 16-8 / 17 / 2010$ & 19.25 & 1.4 & 4.3 & 196 & 11.6 & 146 \\
\hline $2009 \mathrm{~N}-1 \mathrm{~m}-15$ & $8 / 17-8 / 19 / 2010$ & 36.75 & 1.6 & 4.5 & 263 & 10.9 & 304 \\
\hline $2009 \mathrm{~N}-1 \mathrm{~m}-16$ & $9 / 2-9 / 3 / 2010$ & 28 & 1.2 & 3.6 & 207 & 8.1 & 151 \\
\hline
\end{tabular}

Station 2009N significant wave height (SWH) events (1 m- "minor" and 2 m- "major" in italics to designate "SE"), (1 to r) SWH duration, SWH, wave period, wave direction, fetch, wind speed, wind direction for wave record October 3, 2009-September 3, 2010 at $67^{\circ} 38^{\prime} 17.76^{\prime \prime} \mathrm{N}, 164^{\circ} 20^{\prime} 46.26^{\prime \prime} \mathrm{W}$, north location near Kivalina, AK, water depth $17 \mathrm{~m}$

a 2009 N-2m-12 (also known as SE3)

"2009N-2m-12" known as SWH Event 3 or "SE3" (from Table 1), July 22-23, 2010, event "2009S-2m-15" known as SWH Event 4 or "SE4" (from Table 2), July 16-18, 2010, and event "2009S-2m-20" known as SWH Event 5 or "SE5" (from Table 2), 
Table 2 Station 2009S significant wave height events $\geq 1 \mathrm{~m}$

\begin{tabular}{|c|c|c|c|c|c|c|c|}
\hline SWH event & Date & $\begin{array}{l}\text { SWH } \\
\text { duration (h) }\end{array}$ & $\begin{array}{l}\mathrm{Hm} 0 \\
(\mathrm{~m})\end{array}$ & $\begin{array}{l}\mathrm{Tm} 02 \\
\text { (s) }\end{array}$ & $\begin{array}{l}\text { Wave } \\
\operatorname{dir}\left({ }^{\circ}\right)\end{array}$ & $\begin{array}{l}\text { Wind } \\
\operatorname{spd}(\mathrm{m} / \mathrm{s})\end{array}$ & $\begin{array}{l}\text { Wind } \\
\operatorname{dir}\left(^{\circ}\right)\end{array}$ \\
\hline 2009S-1m-1 & $10 / 3-10 / 4 / 2009$ & 19.25 & 1.2 & 3.9 & 147 & 5.7 & 86 \\
\hline 2009S-1m-2 & $10 / 7-10 / 10 / 2009$ & 61.25 & 1.7 & 4.3 & 150 & 7.3 & 97 \\
\hline 2009S-1m-3 & $10 / 10-10 / 12 / 2009$ & 38.5 & 1.2 & 3.8 & 156 & 8.0 & 116 \\
\hline 2009S-1m-4 & $10 / 16-10 / 17 / 2009$ & 26.25 & 1.2 & 4.0 & 285 & 5.0 & 300 \\
\hline 2009S-1m-5 & $10 / 21-10 / 22 / 2009$ & 29.75 & 1.3 & 3.9 & 303 & 8.3 & 23 \\
\hline 2009S-1m-6 & $10 / 26-10 / 27 / 2009$ & 26.25 & 1.3 & 4.7 & 278 & 2.6 & 332 \\
\hline 2009S-1m-7 & $11 / 12-11 / 13 / 2009$ & 22.75 & 1.3 & 6.2 & 280 & 3.8 & 180 \\
\hline 2009S-1m-8 & $11 / 15-11 / 16 / 2009$ & 29.75 & 1.2 & 7.4 & 280 & 2.2 & 178 \\
\hline 2009S-1m-9 & $12 / 5-12 / 5 / 2009$ & 7 & 1.4 & 3.8 & 95 & 12.7 & 112 \\
\hline 2009S-1m-10 & $4 / 15-4 / 15 / 2010$ & 7 & 1.7 & 5.8 & 182 & 2.3 & 184 \\
\hline 2009S-1m-11 & $5 / 26-5 / 27 / 2010$ & 45.5 & 1.3 & 4.7 & 179 & 3.2 & 140 \\
\hline 2009S-1m-12 & $7 / 5-7 / 6 / 2010$ & 31.5 & 1.4 & 4.4 & 284 & 7.1 & 169 \\
\hline 2009S-1m-13 & $7 / 10-7 / 13 / 2010$ & 64.75 & 1.4 & 4.0 & 287 & 5.1 & 306 \\
\hline 2009S-1m-14 & $7 / 14-7 / 15 / 2010$ & 24.5 & 1.4 & 4.0 & 288 & 4.0 & 293 \\
\hline $2009 S-2 m-15^{\mathrm{a}}$ & $7 / 16-7 / 18 / 2010$ & 52.5 & 1.6 & 4.7 & 241 & 6.8 & 194 \\
\hline 2009S-1m-16 & $7 / 22-7 / 24 / 2010$ & 45.5 & 1.7 & 4.7 & 254 & 4.8 & 214 \\
\hline 2009S-1m-17 & $8 / 1-8 / 3 / 2010$ & 56 & 1.2 & 4.2 & 243 & 6.3 & 211 \\
\hline 2009S-1m-18 & $8 / 7-8 / 8 / 2010$ & 7 & 1.2 & 3.6 & 280 & 3.8 & 305 \\
\hline 2009S-1m-19 & $8 / 15-8 / 17 / 2010$ & 50.75 & 1.5 & 3.8 & 158 & 9.4 & 130 \\
\hline $2009 S-2 m-20^{\mathrm{b}}$ & $8 / 17-8 / 20 / 2010$ & 61.25 & 2.0 & 4.4 & 279 & 6.1 & 304 \\
\hline 2009S-1m-21 & $8 / 23-8 / 24 / 2010$ & 21 & 1.1 & 3.7 & 259 & 4.0 & 301 \\
\hline 2009S-1m-22 & $8 / 31-8 / 31 / 2010$ & 14 & 1.2 & 3.8 & 292 & 3.3 & 306 \\
\hline $2009 \mathrm{~S}-1 \mathrm{~m}-23$ & $9 / 2-9 / 2 / 2010$ & 22.75 & 1.2 & 3.8 & 223 & 6.7 & 147 \\
\hline 2009S-1m-24 & $9 / 3-9 / 3 / 2010$ & 14 & 1.3 & 3.8 & 149 & 5.7 & 122 \\
\hline $2009 \mathrm{~S}-1 \mathrm{~m}-25$ & $9 / 7-9 / 7 / 2010$ & 7 & 1.3 & 3.5 & 158 & 6.9 & 100 \\
\hline
\end{tabular}

Station 2009S significant wave height (SWH) events (1 m- "minor" and 2 m- "major" in italics to designate "SE") (1 to r) SWH duration, SWH, wave period, wave direction, fetch, wind speed, wind direction for wave record October 3, 2009-September 9, 2010 at $67^{\circ} 10^{\prime} 33.30^{\prime \prime} \mathrm{N}, 163^{\circ} 59^{\prime} 23.94^{\prime \prime} \mathrm{W}$, south location near Cape Krusenstern, AK, water depth $18 \mathrm{~m}$

a $2009 \mathrm{~S}-2$ m-15 (also known as SE4)

b 2009S-2 m-20 (also known as SE5)

August 17-20, 2010. For these three events, the wave signal evolution is reviewed, followed by an examination of the lifecycle of the storm, and atmospheric forcing identified as the cause for that SWH event. Also, consideration of near-surface winds at the RDCP location in the context of fetch is presented. Finally, for Stations 2009N and 2009S, the $\mathrm{SWH}\left(H_{m 0}\right)$ and mean wave direction $\left(D_{m}\right)$ were compared for all three SWH events.

\subsection{SE3 (2009N-2m-12), July 22-23, 2010 UTC}

The event identified as SE3 (2009N-2 m-12) commenced July 220800 UTC (all times are given in UTC) and ended July 232100 , for a total duration of $37 \mathrm{~h}$ with SWH in excess of $1 \mathrm{~m}$ (Fig. 10). In brief, the storm took the form of a cyclonic pattern, with a low pressure 
centered over the Chukchi Sea/Arctic Ocean, between Wrangel Island and Alaska. Winds were southerly and highest over the eastern Chukchi Sea coast to the north of Bering Strait. On the western flank of the storm, northerly winds extended from the Arctic Ocean to the northern Siberian coast. The SWH event proceeded as follows (Fig. 10): the SWH increased rapidly from $\sim 0.96-2.42 \mathrm{~m}$ over a 9-h period after which this "peak" wave state persisted for $7 \mathrm{~h}$, before SWH decreased gradually to $0.92 \mathrm{~m}$ over the next $26 \mathrm{~h}$. Fig. 11 shows that the event began with waves from the west at $1 \mathrm{~m} \mathrm{SWHs,} \mathrm{which} \mathrm{then} \mathrm{became}$ southwesterly as SWH reached $2 \mathrm{~m}$, and then returned to a westerly direction as SWH tapered down to $1 \mathrm{~m}$.

The primary feature of the synoptic situation (Fig. 12) that gave rise to these events observed through SE3 were the winds associated with the low pressure system in the northeast Chukchi Sea that began on July 21 2100. A high pressure system bordered the low pressure system along the southeast Chukchi Sea; the resulting pressure gradient

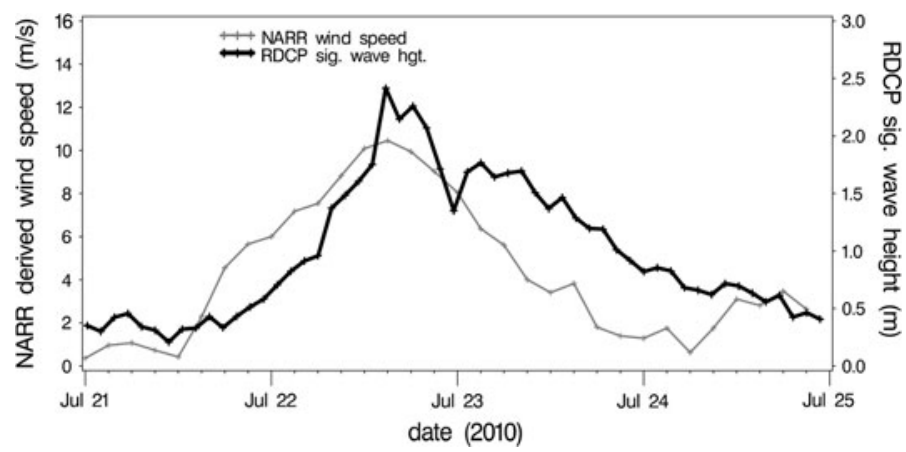

Fig. 10 SE3 wave height versus wind speed. Comparison of recording Doppler current profiler (RDCP) significant wave height (SWH) and North American regional reanalysis (NARR) $10 \mathrm{~m}$ wind speed at Station $2009 \mathrm{~N}$ for wave record July 22-23, 2010 (SE3). Station location and depth are $67^{\circ} 38^{\prime} 17.76^{\prime \prime} \mathrm{N}$, $164^{\circ} 20^{\prime} 46.26^{\prime \prime} \mathrm{W}$ (near Kivalina, AK), and 17 m, respectively

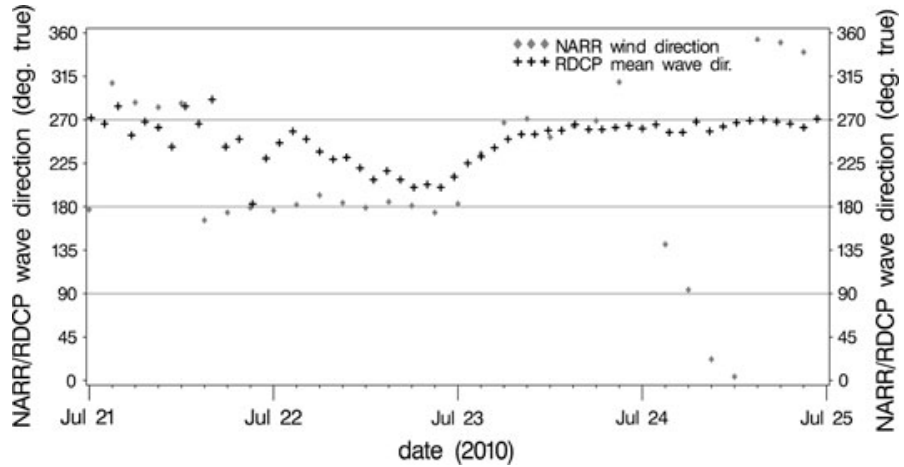

Fig. 11 SE3 wave direction versus wind direction. Comparison of recording Doppler current profiler (RDCP) mean wave direction and North American regional reanalysis (NARR) $10 \mathrm{~m}$ wind direction at Station $2009 \mathrm{~N}$ for wave record July 22-23, 2010 (SE3). Station location and depth are $67^{\circ} 38^{\prime} 17.76^{\prime \prime} \mathrm{N}$, $164^{\circ} 20^{\prime} 46.26^{\prime \prime} \mathrm{W}$ (near Kivalina, AK), and $17 \mathrm{~m}$, respectively 


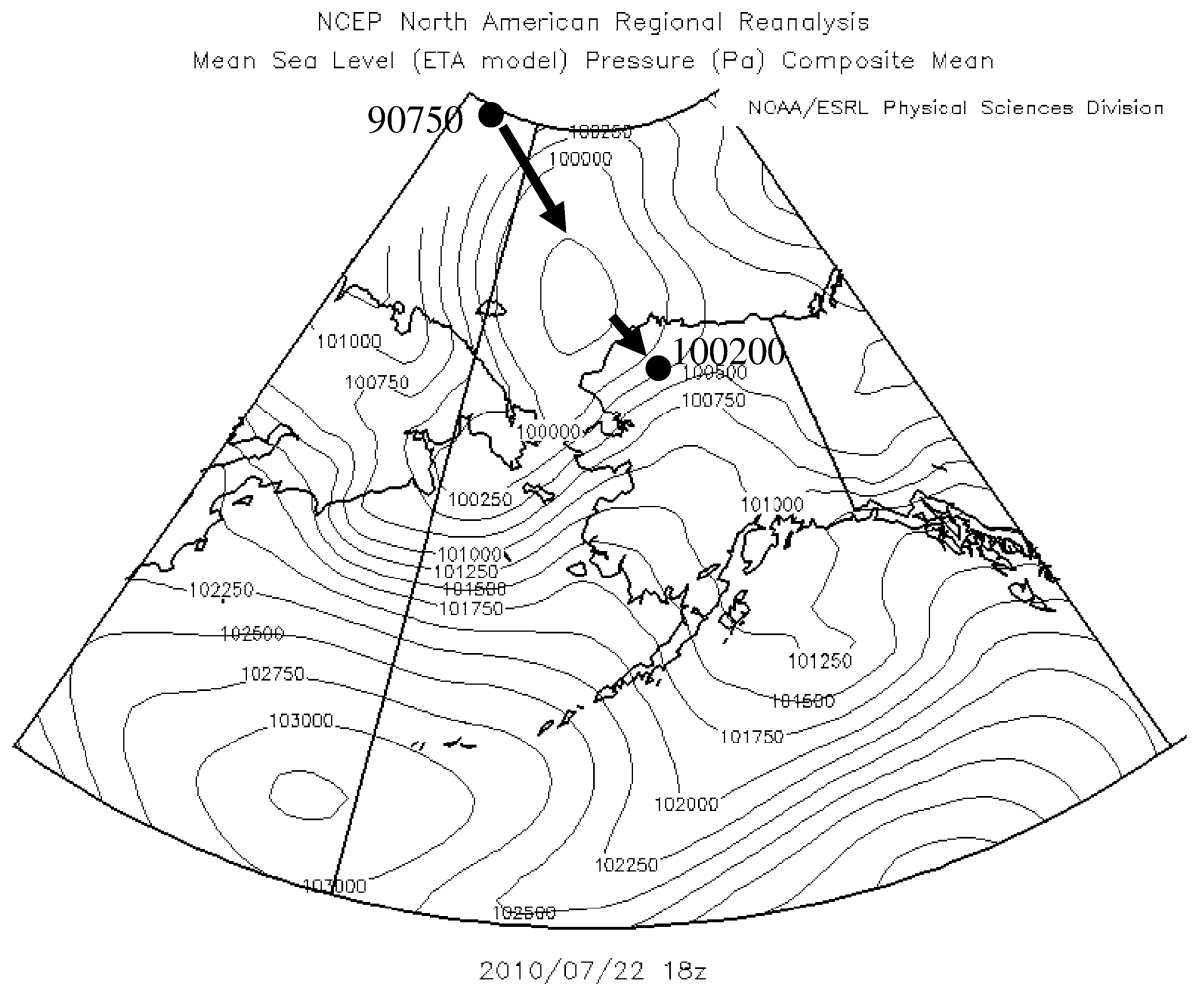

Fig. 12 SE3 storm maxima. Storm maxima during SE3 on July 22, 20101800 UTC shown on North American regional reanalysis (NARR) Mean Sea level pressure (MSLP) map. Image provided by the NOAA-ESRL Physical sciences division, Boulder Colorado at http://www.esrl.noaa.gov/psd. Modified by O. Francis, January 2011

favored strong southwesterly winds in the southeast Chukchi Sea region. As the low moved south-southeast, toward the northern Alaska coast, the high pressure system did not move. This caused the pressure gradient to strengthen with a concomitant increase in the wind speed $(925 \mathrm{hPa})$ over Station $2009 \mathrm{~N}$ from 10 to $14 \mathrm{~m} \mathrm{~s}^{-1}$ in $6 \mathrm{~h}$. By the start of SE3, wind speeds were at $15 \mathrm{~m} \mathrm{~s}^{-1}$ over Station $2009 \mathrm{~N}$.

The peak of the "storm" was from July 221500 to July 222200 (7 h). The $925 \mathrm{hPa}$ geopotential height remained moderately low $(650-660 \mathrm{~m})$ during this period and the storm domain extended southward to Bering Strait. The juxtaposition with the high pressure system farther south resulted in strong southwesterly winds $\left(18 \mathrm{~m} \mathrm{~s}^{-1}\right)$ over the Bering Strait, Seward Peninsula, and SE Chukchi Sea regions. The mean sea level pressure (MSLP) for this storm event reached and remained at its minimum of $975 \mathrm{hPa}$ for a 24-h period from July 212100 to July 22 2100. This time frame encompassed the beginning of SE3 starting when SWH exceeded $1 \mathrm{~m}$ through the period during which SWH was $>2 \mathrm{~m}$. The storm intensity began to wane on July 23 1200; the duration of $1 \mathrm{~m} \mathrm{SWH's} \mathrm{lasted} \mathrm{only}$ a few hours longer. By July 23 0300, $925 \mathrm{hPa}$ winds over Station 2009N had decreased to and $8 \mathrm{~m} / \mathrm{s}$ and became westerly.

Figure 13 shows the wave spectrum at the highest SWH during 22 July 1400, which was at the beginning of the peak storm period over the Bering Strait (22 July 1500 to 22 July 
Fig. 13 SE3 wave spectrum. Directional (top) and non-directional (bottom) wave spectra Cartesian projection of highest SWH in SE3 on July 22, 20101446 UTC, SWH $=2.4 \mathrm{~m}$ recorded by the recording Doppler current profiler (RDCP) at Station $2009 \mathrm{~N}$ at $67^{\circ} 38^{\prime} 17.76^{\prime \prime} \mathrm{N}, 164^{\circ} 20^{\prime} 46.26^{\prime \prime} \mathrm{W}$ (near Kivalina, AK), and with a water depth of $17 \mathrm{~m}$. The color bar (top) and non-directional (bottom) gives the wave energy density, $E(f)$, in $\mathrm{m}^{2} \mathrm{~Hz}^{-1}$

2200). Although, the peak storm event began at 22 July 1500, highest wind speeds $\left(10 \mathrm{~m} \mathrm{~s}^{-1}\right)$ began $4 \mathrm{~h}$ earlier which continued throughout the peak storm event. The color bar (top) and non-directional (bottom) gives the wave energy density, $E(f)$, in $\mathrm{m}^{2} \mathrm{~Hz}^{-1}$. The Cartesian contour plot (Fig. 13-top) shows that the spectra ranges from 0.14 to $0.23 \mathrm{~Hz}$ and an $80^{\circ}$ direction range for $E(f)>0.15 \mathrm{~m}^{2} \mathrm{~Hz}^{-1}$. This was a much smaller wave energy density than what was seen in Francis and Atkinson (2012) for the offshore. The non-directional peak energy density was $3.3 \mathrm{~m}^{2} \mathrm{~Hz}^{-1}$ (Fig. 13-bottom) at $0.17 \mathrm{~Hz}$, while the directional (Fig. 13-top) was centered at $0.22 \mathrm{~Hz}$ coming from $217^{\circ}$ (southwest). The corresponding wave parameters were $\mathrm{SWH}=2.4 \mathrm{~m}, \quad T_{m 02}=4.4 \mathrm{~s}$, $\mathrm{T}_{m 01}=4.7 \mathrm{~s}$. The mean winds during the period of the spectrum included a wind speed of $U_{10}=10.5 \mathrm{~m} \mathrm{~s}^{-1}$ and a wind direction of $U_{\mathrm{dir}}=185^{\circ}$. Although wind and wave direction were southwesterly, wave direction $\left(217^{\circ}\right)$ was at a $32^{\circ}$ difference clockwise from wind direction $\left(185^{\circ}\right)$. The wave phase speed is given by $g / 2 \pi f_{p}$ (Ewing 1980), where $f_{p}$ is the peak frequency or the inverse of the peak period. With the wind speed $\left(10.5 \mathrm{~m} \mathrm{~s}^{-1}\right)$ and the RDCP peak period, $f_{p}(4.7 \mathrm{~s})$, the wind speed was greater than the wave phase speed $\left(7.3 \mathrm{~m} \mathrm{~s}^{-1}\right)$. When the wind speed is greater than the wave phase speed, this indicates "wind-sea". When the wind speed is less than the wave phase speed, this indicates "swell". Since the wind speed was greater than the wave phase speed, this indicates a southwesterly "wind-sea" for the event of 22 July 1400.

At the beginning of SE3, the 10-m surface wind over Station 2009N was southerly at $7.5 \mathrm{~m} \mathrm{~s}^{-1}$ from the vicinity of the Seward Peninsula and Bering Strait. The wave direction was southwesterly to south-southwesterly, therefore took on a more western direction than the wind direction. During the first $3 \mathrm{~h}$, the wind magnitude increased rapidly from 7 to $10 \mathrm{~m} \mathrm{~s}^{-1}$. By July 23 0300, both surface wind and wave direction over Station 2009N became westerly, corresponding almost perfectly. After remaining at a peak of $10 \mathrm{~m} \mathrm{~s}^{-1}$ for $9 \mathrm{~h}$, the wind magnitude decreased to $6.4 \mathrm{~m} \mathrm{~s}^{-1}$ within $7 \mathrm{~h}$.

It was of interest to determine whether the NARR winds, as applied to a theoretical wave growth exercise, were able to reproduce the observed $2.4 \mathrm{~m} \mathrm{SWH}$ that was shown for the wave spectrum. The time of propagation, $t$, in deep water is $t=4 \pi X /(g T)$ where $X$ is the fetch, and $T$ is the wave period. The fetch $(X)$ was estimated to be $129 \mathrm{~km}$ to the SSW of the RDCP. The wave period $(T)$ was $4.7 \mathrm{~s}$. This resulted in a time of propagation $(t)$ for the wave at $9.7 \mathrm{~h}$. This would identify the timing of the wave generation to begin at July 22 0500. According the NARR data set, southerly wind speeds averaging $8 \mathrm{~m} / \mathrm{s}$ started and continued for $9 \mathrm{~h}$ throughout this time.

In summary, it appears that the Chukchi Sea low present on July 22 played a major role in wave development during SE3, generating moderate southwesterly winds. These winds, which were of a magnitude typical in this region, drove a wave state with southwesterly SWH exceeding $2 \mathrm{~m}$.

\subsection{SE4 (2009S-2m-15), July 16-18, 2010 UTC}

SE4 (2009S-2m-15) commenced July 160500 and ended July 180900 (52 h duration). In brief, the event proceeded as follows (Fig. 14): the SWH cycled between 1 and $2 \mathrm{~m}$ for a 

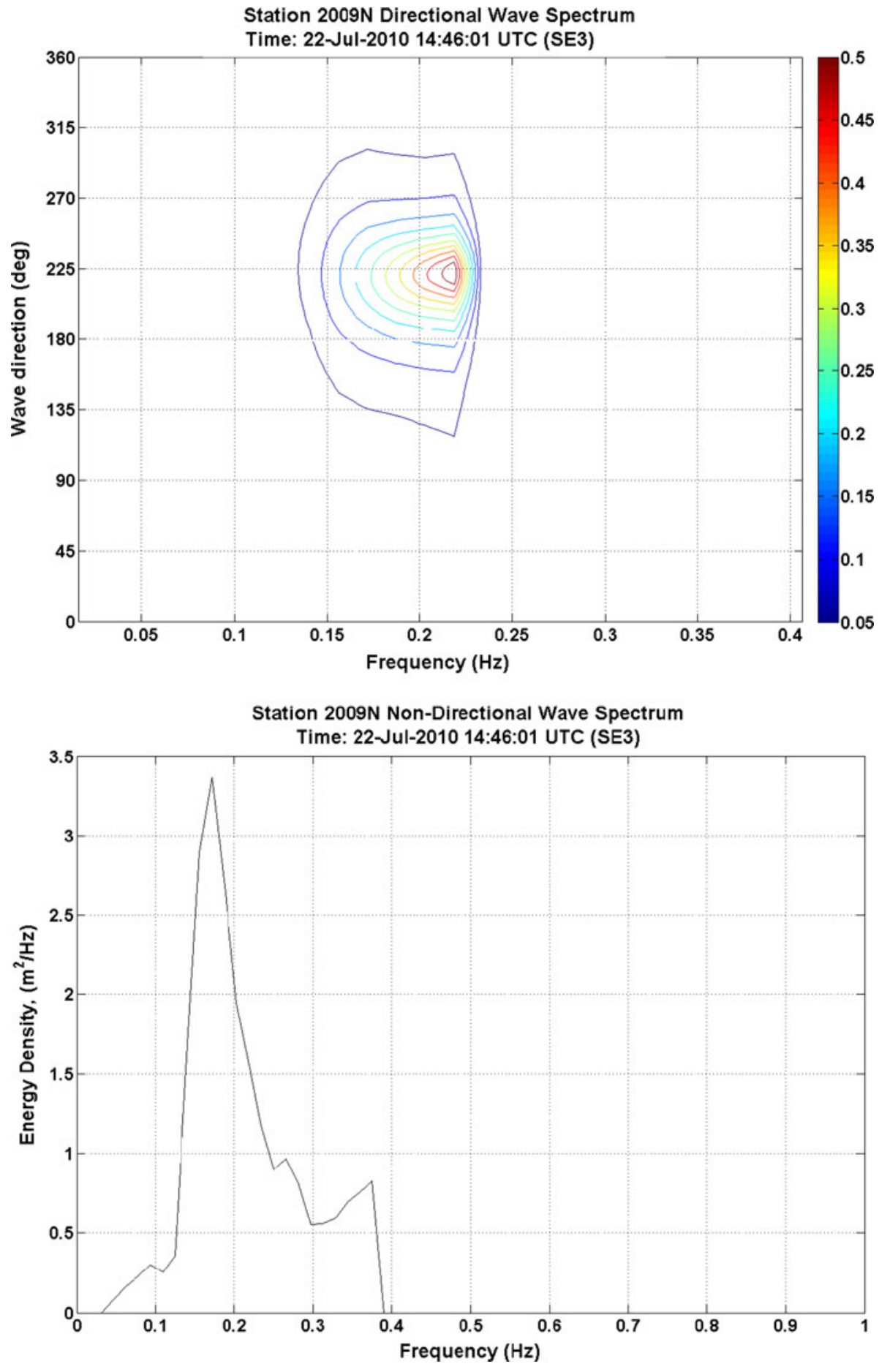


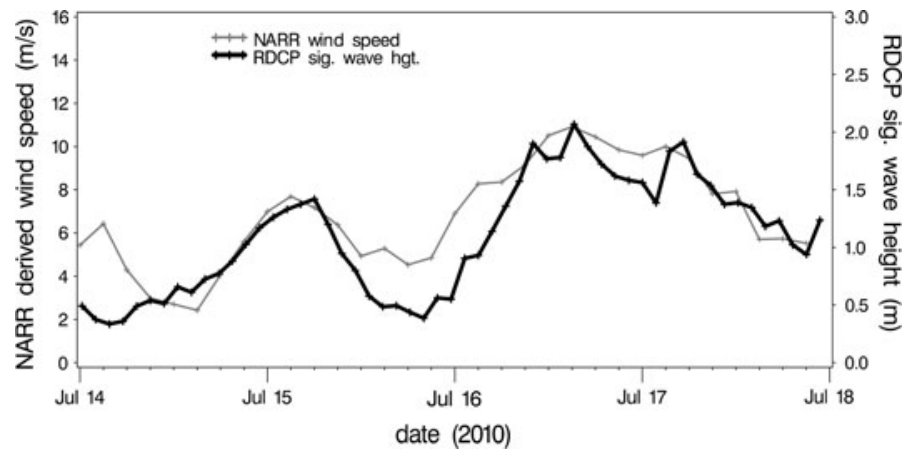

Fig. 14 SE4 wave height versus wind speed. Comparison of recording Doppler current profiler (RDCP) significant wave height (SWH) and North American regional reanalysis (NARR) $10 \mathrm{~m}$ wind speed at Station 2009 S for wave record July 16-18, 2010 (SE4). Station location and depth are $67^{\circ} 10^{\prime} 33.30^{\prime \prime} \mathrm{N}$, $163^{\circ} 59^{\prime} 23.94^{\prime \prime} \mathrm{W}$ (near Cape Krusenstern, AK), and $18 \mathrm{~m}$, respectively

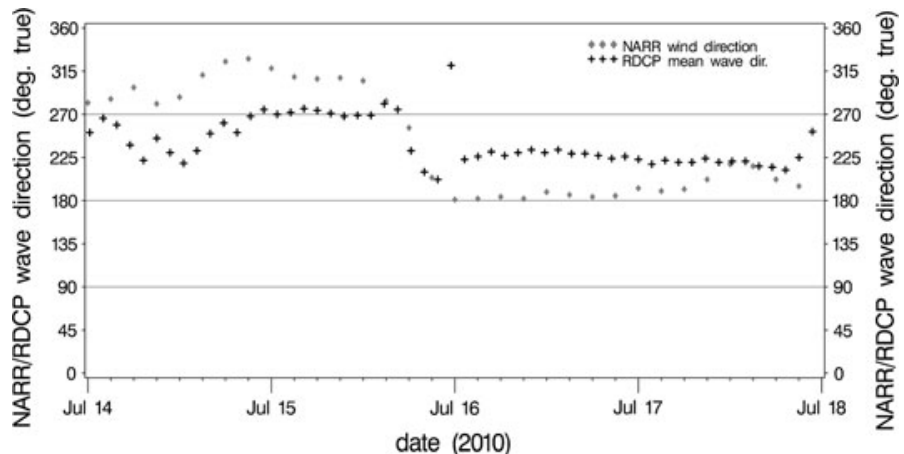

Fig. 15 SE 4 wave direction versus wind direction. Comparison of recording Doppler current profiler (RDCP) mean wave direction and North American regional reanalysis (NARR) $10 \mathrm{~m}$ wind direction at Station 2009 S for wave record July 16-18, 2010 (SE4). Station location and depth are $67^{\circ} 10^{\prime} 33.30^{\prime \prime} \mathrm{N}$, $163^{\circ} 59^{\prime} 23.94^{\prime \prime} \mathrm{W}$ (near Cape Krusenstern, AK), and $18 \mathrm{~m}$, respectively

23-h period, then averaged $2.2 \mathrm{~m} \mathrm{SWH}$ for $12 \mathrm{~h}$, and finally a decreased to between 1 and $2 \mathrm{~m}$ for $17.5 \mathrm{~h}$ before termination. More specifically, the event began with a $1 \mathrm{~m} \mathrm{SWH}$ with a southwesterly wave direction for $3.5 \mathrm{~h}$, then west-southwesterly direction for the next $17.5 \mathrm{~h}$, then southwesterly for the next $21 \mathrm{~h}$, then westerly for the last $10.5 \mathrm{~h}$ (Fig. 15). The "peak" wave states (i.e., SWH $\geq 2 \mathrm{~m}$ ) were from the southwest.

The synoptic situation during this period (Fig. 16) prominently featured a low pressure system that began over the Western Chukchi Sea and Wrangel Island from July 15 to 17. The low was bordered to the southeast by a strong high pressure ridge extending northeast to east over the eastern to northern Bering Sea region. This resulted in the highest wind speeds over the Chukchi Sea, Kotzebue Sound, and Bering Strait region. This storm moved southeast over the Chukchi Sea toward northern Alaska with maximum winds of $16-18 \mathrm{~m} \mathrm{~s}^{-1}$ at $925 \mathrm{hPa}$. By July 171800 , the low had stalled and then weakened to a central pressure of $1007 \mathrm{hPa}$. This low pressure system remained in this state through the end of the SWH event at 0900 on July 18. 


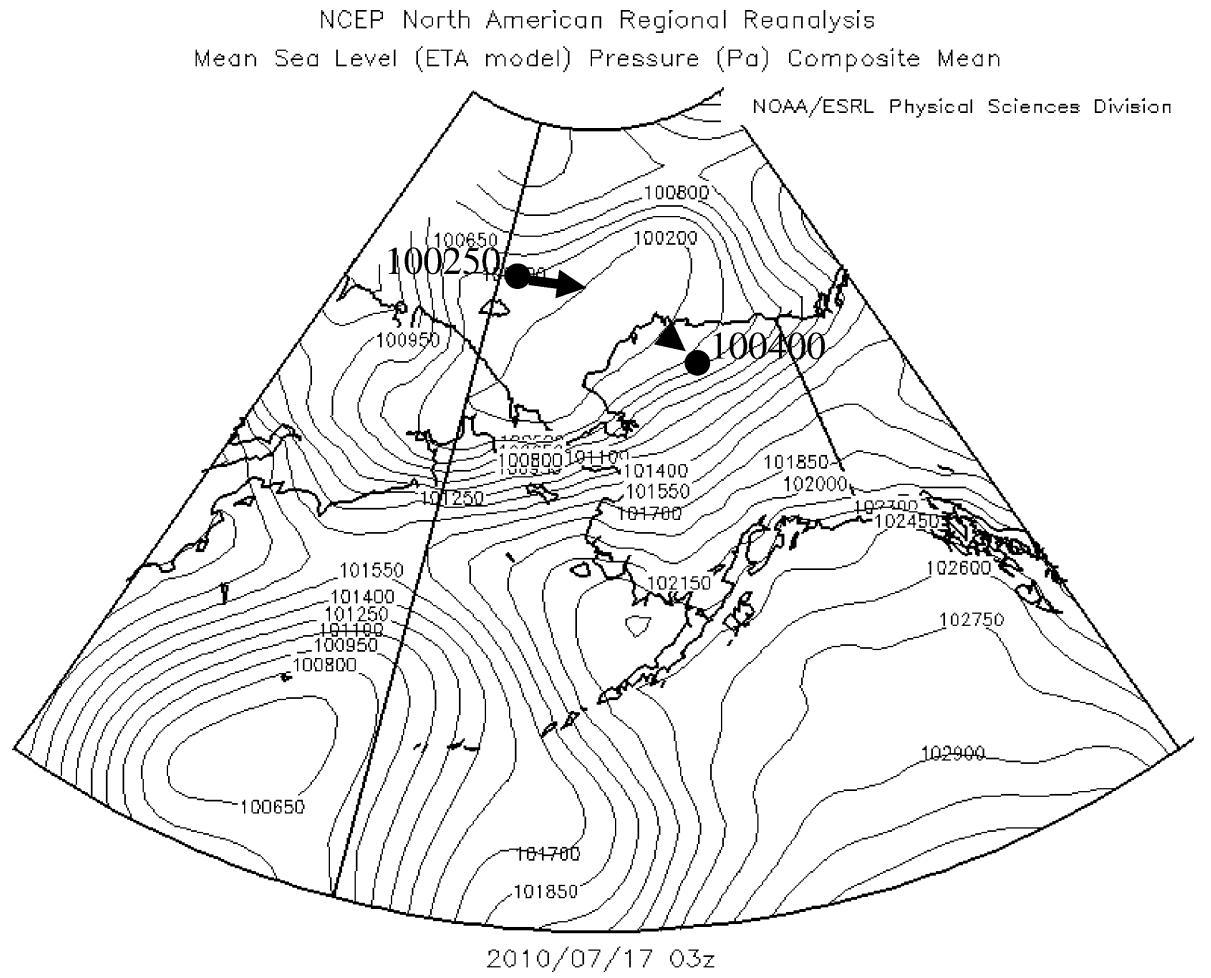

Fig. 16 SE4 storm maxima. Storm maxima during SE4 on July 17, 20100300 UTC shown on North American regional reanalysis (NARR) Mean sea level pressure (MSLP) map. Image provided by the NOAA-ESRL Physical Sciences Division, Boulder Colorado at http://www.esrl.noaa.gov/psd. Modified by O. Francis, January 2011

The peak of the "storm" occurred from July 161200 to July 170900 (21 h). MSLP reached a minimum of 1,002 hPa for $36 \mathrm{~h}$ from July 152100 to July 17 0900; the center of the low moved eastward from Wrangel Island to the eastern Chukchi Sea on the Alaskan coast. The slight drop in MSLP on July 17 immediately preceded the more active phase of SE4.

Figure 17 shows the wave spectrum during one of the higher SWH during 17 July 0800 , which was near the end of the peak storm period over the Chukchi Sea (16 July 1200 to 17 July 0900). This was also at the end of the highest wind speeds $\left(8-9 \mathrm{~m} \mathrm{~s}^{-1}\right)$ that lasted about the same amount of time as the peak storm event, and lasted $20 \mathrm{~h}$ over the SE Chukchi Sea. The color bar (top) and non-directional (bottom) gives the wave energy density $(E(f))$ in $\mathrm{m}^{2} \mathrm{~Hz}^{-1}$. Figure 17 indicates that the spectra range from 0.14 to $0.21 \mathrm{~Hz}$ and a $90^{\circ}$ direction range for $E(f)>0.10 \mathrm{~m}^{2} \mathrm{~Hz}^{-1}$. The non-directional peak energy density was $2.6 \mathrm{~m}^{2} \mathrm{~Hz}^{-1}$ (Fig. 13-bottom) at $0.15 \mathrm{~Hz}$, while the directional (Fig. 13top) was centered at $0.2 \mathrm{~Hz}$ coming from $225^{\circ}$ (southwest). The wave parameters for this particular spectrum were $\mathrm{SWH}=2.1 \mathrm{~m}, T_{m 02}=4.5 \mathrm{~s}, T_{m 01}=4.7 \mathrm{~s}$. The mean winds during the period of the spectrum included a wind speed of $U_{10}=7.0 \mathrm{~m} \mathrm{~s}^{-1}$ and a wind direction of $U_{\mathrm{dir}}=200^{\circ}$. Although wind and wave direction were southwesterly, wave direction $\left(225^{\circ}\right)$ was at a $25^{\circ}$ difference clockwise from wind direction $\left(200^{\circ}\right)$. With the 
Fig. 17 SE4 wave spectrum. Directional (top) and non-directional (bottom) wave spectra Cartesian projection of highest SWH in SE4 on July 17, 20100846 UTC, SWH $=2.1 \mathrm{~m}$ recorded by the recording Doppler current profiler (RDCP) at Station 2009S at $67^{\circ} 10^{\prime} 33.30^{\prime \prime} \mathrm{N}, 163^{\circ} 59^{\prime} 23.94^{\prime \prime} \mathrm{W}$ (near Cape Krusenstern, AK), and with a water depth of $18 \mathrm{~m}$. The color bar (top) and non-directional (bottom) gives the wave energy density, $E(f)$, in $\mathrm{m}^{2} \mathrm{~Hz}^{-1}$

wind speed $\left(7.0 \mathrm{~m} \mathrm{~s}^{-1}\right)$ and the RDCP peak period, $f_{p}(4.7 \mathrm{~s})$, the wind speed was less than the wave phase speed $\left(7.3 \mathrm{~m} \mathrm{~s}^{-1}\right)$. Since the wind speed is less than the wave phase speed, this indicates a southwesterly "swell" for the event of 17 July 0800.

Similar to SE3, the SWHs represented surface winds $(10 \mathrm{~m})$ as indicated by their directions. During the first part of SE4, winds were predominantly south-southwesterly, while waves were southwesterly to west-southwesterly. Beginning July 16 1400, surface wind direction changed to southerly, while wave direction remained west-southwesterly. As the "peak" wave state (i.e., SWH $\geq 2 \mathrm{~m}$ ) began to occur, the surface wind direction became south-southwesterly, while the wave direction became southwesterly. During the final stages of SE4, the surface wind direction was southerly, while the wave direction was westerly. Therefore, wave direction always remained more westerly than the wind direction, similar to what happened in the case of SE3.

It was again of interest to determine whether the variation in NARR winds was compatible to the observed $2.1 \mathrm{~m} \mathrm{SWH}$ that was shown for the wave spectrum. The time of propagation, $t$, in deep water is $t=4 \pi X /(g T)$ where $X$ is the fetch, and $T$ is the wave period. The fetch $X$ to the SSW of the RDCP was estimated at $97 \mathrm{~km}$. The wave period $T$ was $4.7 \mathrm{~s}$. This resulted in a time of propagation $t$ for the wave at $7.3 \mathrm{~h}$. This would put the wave generation beginning at July 170100 . According the NARR data set, SSW wind speeds of $8 \mathrm{~m} \mathrm{~s}^{-1}$ occurred around the beginning of this time and continued until July 17 0800. Therefore, the winds are consistent with the wave propagation.

In summary, the Chukchi Sea low present during July 15-17 played a major role in wave development during SE4, generating moderate southwesterly winds. This was similar to what occurred for SE3 but with a less pronounced cyclonic storm system.

\subsection{SE5 (2009S-2m-20), August 17-20, 2010 UTC}

SE5 (2009S-2m-20) commenced August 171700 and ended August $200600(61 \mathrm{~h}$ duration). In brief, the event proceeded as follows (Fig. 18): SWH started at $1.2 \mathrm{~m}$ and rose to $2.2 \mathrm{~m}$ during the first $7 \mathrm{~h}$ period, then were between 2 and $4 \mathrm{~m}$ for $33 \mathrm{~h}$, and finally decreased from 1.8 to $1.0 \mathrm{~m}$ during the last $20.5 \mathrm{~h}$ before terminating. More specifically, for the first $31 \mathrm{~h}$, the wave direction was westerly which included part of the "peak" wave state (Fig. 19). Then, the wave direction became west-northwesterly for the next $26 \mathrm{~h}$ during the remaining "peak" wave state, before becoming westerly in the final $3.5 \mathrm{~h}$.

The synoptic situation during this period (Fig. 20) featured most prominently a large low pressure system over the Brooks Range in northern Alaska during August 17-18, which was bordered to the west by a high pressure system over Chukotskoye Nagor'ye. This resulted in the highest wind speeds over the eastern Chukchi Sea and Kotzebue Sound. The MSLP was $1,000 \mathrm{hPa}$ supporting maximum winds of $16 \mathrm{~m} \mathrm{~s}^{-1}$ at $925 \mathrm{hPa}$. This storm migrated north from the Brooks Range to the northeastern Chukchi Sea during August 17-19 as the low pressure system weakened to an MSLP of $1005 \mathrm{hPa}$. The final stage of this low pressure system was marked by its further weakening to a central MSLP 

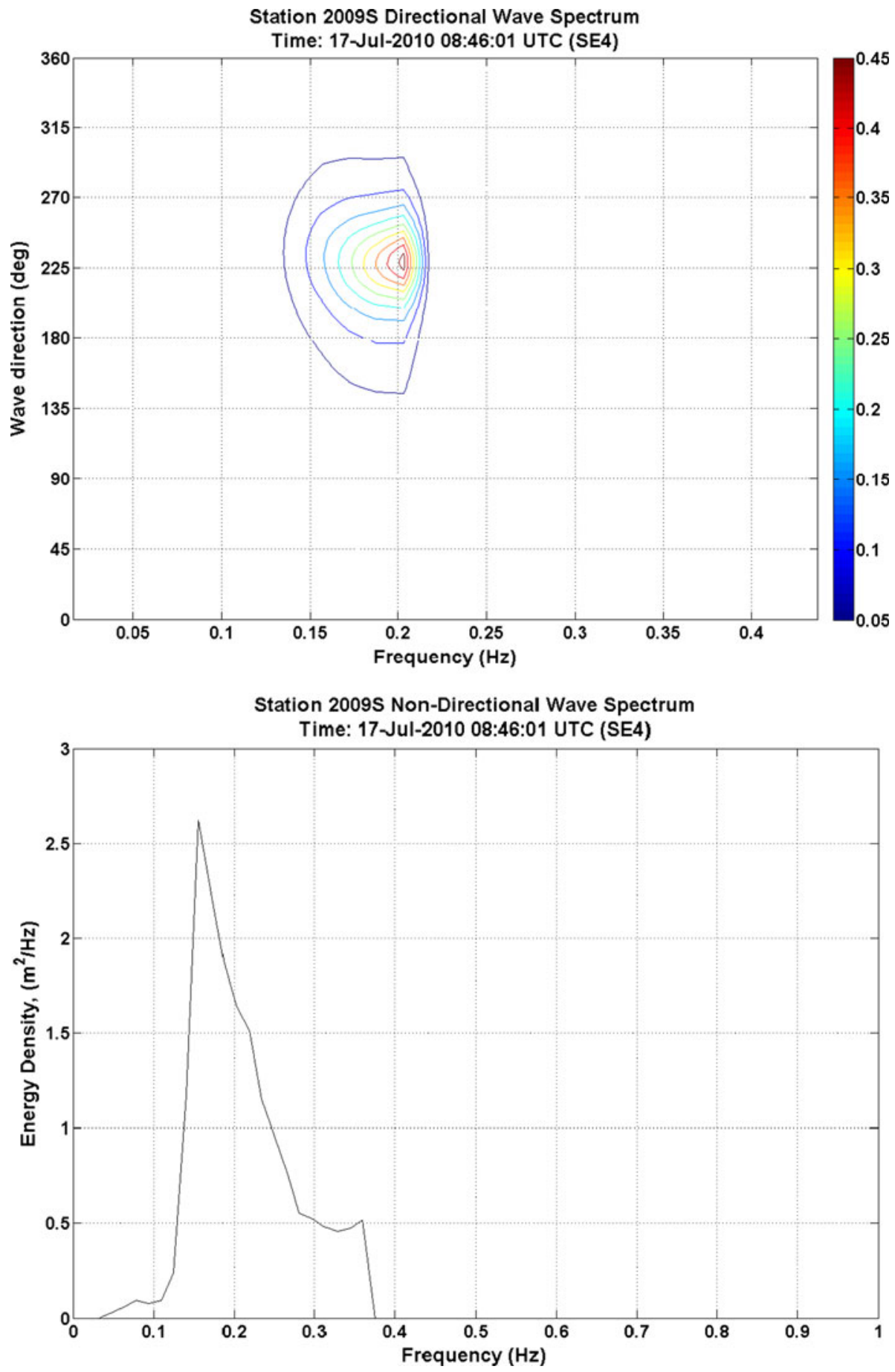


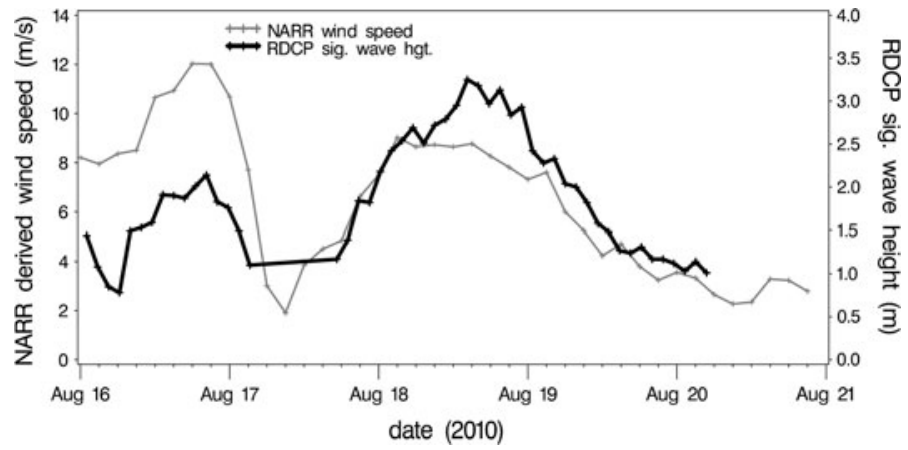

Fig. 18 SE5 wave height versus wind speed. Comparison of recording Doppler current profiler (RDCP) significant wave height $(\mathrm{SWH})$ and North American regional reanalysis (NARR) $10 \mathrm{~m}$ wind speed at Station $2009 \mathrm{~S}$ for wave record August 17-20, 2010 (SE5). Station location and depth are $67^{\circ} 10^{\prime} 33.30^{\prime \prime} \mathrm{N}$, $163^{\circ} 59^{\prime} 23.94^{\prime \prime} \mathrm{W}$ (near Cape Krusenstern, AK), and $18 \mathrm{~m}$, respectively

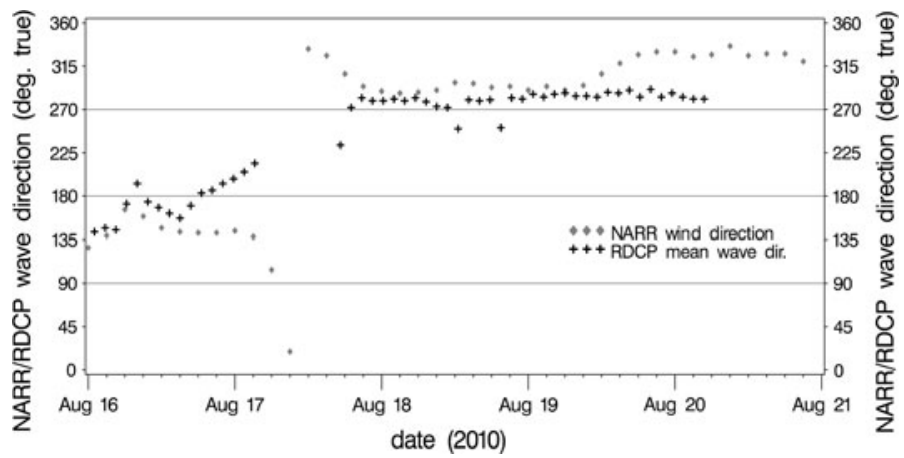

Fig. 19 SE5 wave direction versus wind direction. Comparison of recording Doppler current profiler (RDCP) mean wave direction and North American regional reanalysis (NARR) $10 \mathrm{~m}$ wind direction at Station 2009S for wave record August 17-20, 2010 (SE5). Station location and depth are $67^{\circ} 10^{\prime} 33.30^{\prime \prime} \mathrm{N}$, $163^{\circ} 59^{\prime} 23.94^{\prime \prime} \mathrm{W}$ (near Cape Krusenstern, AK), and 18 m, respectively

of $1015 \mathrm{hPa}$ on August 20 0300, as it left the Chukchi Sea and moved north over the Arctic Ocean.

The peak of the "storm" occurred from August 180000 to August 190600 (30 h). Corresponding winds $(925 \mathrm{hPa})$ during this time were northwesterly over the eastern Chukchi Sea, and Kotzebue Sound reaching speeds of $16 \mathrm{~m} \mathrm{~s}^{-1}$. MSLP reached a minimum of 1,000 hPa for $24 \mathrm{~h}$ from August 171500 to August 18 1500; the center of the low remained over the Brooks Range.

Unlike SE3 and SE4 where wind direction was at a more southerly direction with respect to wave direction, SE5 wave direction was more northerly with respect to wind direction throughout the wave record. Winds were predominantly west-northwesterly, while waves were westerly, during the first part of SE5. Starting at August 19 0100, the wave direction changed to west-northwesterly, while wind direction remained westnorthwesterly. On August 19 1100, the surface wind direction changed to northwesterly to north-northwesterly, while wave direction remained the same (i.e., west-northwesterly). 


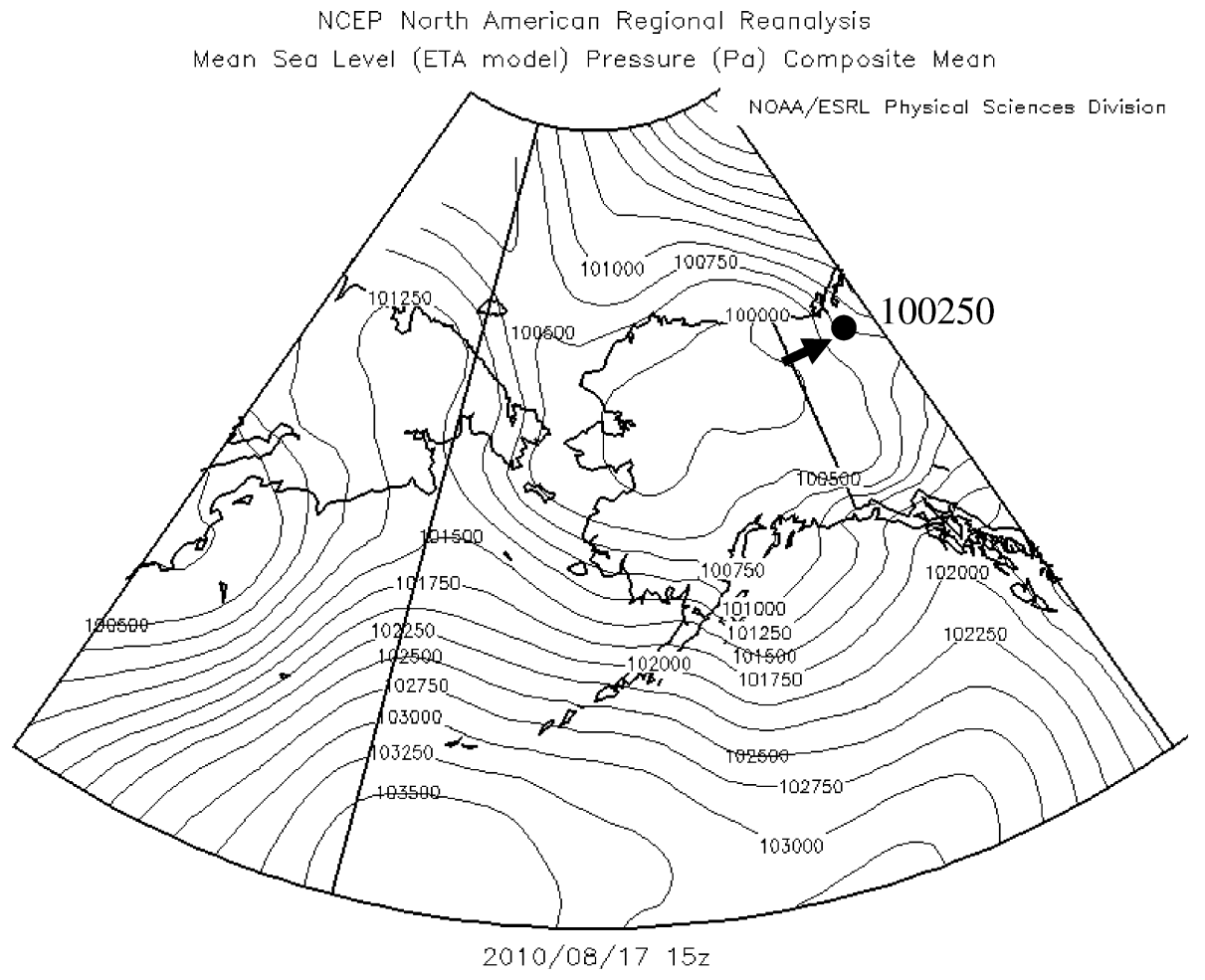

Fig. 20 SE5 storm maxima. Storm maxima during SE5 on August 17, 20101500 UTC shown on North American regional reanalysis (NARR) Mean sea level pressure (MSLP) map. Image provided by the NOAA-ESRL Physical Sciences Division, Boulder Colorado at http://www.esrl.noaa.gov/psd. Modified by O. Francis, Jan 2011

Figure 21 shows the wave spectrum at one of the higher SWH during 18 August 1700, which was in the middle of the peak storm period over the eastern Chukchi Sea and Kotzebue Sound (18 Aug 0000 to 19 Aug 0600). The peak storm event began at 18 August 0000 , and the highest wind speeds $\left(10 \mathrm{~m} \mathrm{~s}^{-1}\right)$ began $2 \mathrm{~h}$ after continuing throughout the peak storm event. The Cartesian contour plot (Fig. 21) shows that the spectra range from 0.13 to $0.22 \mathrm{~Hz}$ and a $110^{\circ}$ direction range for $E(f)>0.20 \mathrm{~m}^{2} \mathrm{~Hz}^{-1}$, a higher energy density than for SE3 and SE4. The non-directional peak energy density was $7.0 \mathrm{~m}^{2} \mathrm{~Hz}^{-1}$ (Fig. 13-bottom) at $0.14 \mathrm{~Hz}$, while the directional (Fig. 13-top) was centered at $0.2 \mathrm{~Hz}$ coming from $280^{\circ}$ (west). The wave characteristics for this particular spectrum were $\mathrm{SWH}=3.0 \mathrm{~m}, T_{m 02}=5.2 \mathrm{~s}, T_{m 01}=5.5 \mathrm{~s}$. The mean winds during the period of the spectrum included a wind speed of $U_{10}=8.3 \mathrm{~m} \mathrm{~s}^{-1}$ and a wind direction of $U_{\mathrm{dir}}=293^{\circ}$. Although wind and wave direction were northwesterly, wave direction $\left(280^{\circ}\right)$ was at a $13^{\circ}$ difference counterclockwise from wind direction $\left(293^{\circ}\right)$. This was different compared with what was seen in SE3 and SE4, where wave direction was clockwise of wind direction. The wind speed $\left(8.3 \mathrm{~m} \mathrm{~s}^{-1}\right)$ was again slightly less than the wave phase speed $\left(8.5 \mathrm{~m} \mathrm{~s}^{-1}\right)$. Since the wind speed is less than the wave phase speed, this indicates a westerly "swell" for the event of 18 August 1700 . 
Fig. 21 SE5 wave spectrum. Directional (top) and non-directional (bottom) wave spectra Cartesian projection of highest SWH in SE5 on July 18, 20101416 UTC, SWH $=3.3 \mathrm{~m}$ recorded by the recording Doppler current profiler (RDCP) at Station $2009 \mathrm{~S}$ at $67^{\circ} 10^{\prime} 33.30^{\prime \prime} \mathrm{N}, 163^{\circ} 59^{\prime} 23.94^{\prime \prime} \mathrm{W}$ (near Cape Krusenstern, AK), and with a water depth of $18 \mathrm{~m}$. The color bar (top) and non-directional (bottom) gives the wave energy density, $E(f)$, in $\mathrm{m}^{2} \mathrm{~Hz}^{-1}$

In determining whether the NARR winds provide accurate forcing for the observed $3.0 \mathrm{~m} \mathrm{SWH}$ that was shown for the wave spectrum, the results were consistent and similar to SE4. Given a fetch of $109 \mathrm{~km}$ WNW of the RDCP and a wave period $T$ was $5.5 \mathrm{~s}$, then the time of propagation $(t=4 \pi X /(g T))$ was $7 \mathrm{~h}$. This would put the wave generation start at August 18 1000. Based on analysis of NARR winds, WNW wind speeds averaged $8.8 \mathrm{~m} \mathrm{~s}^{-1}$ over these $7 \mathrm{~h}$.

In summary, it appears that the Brooks Range low during August 17-18 played a major role in wave development during SE5, generating moderate northwesterly winds from a cyclonic storm system.

\subsection{Comparison of Station 2009N and 2009S for SE3, SE4, and SE5}

For SE3, Station $2009 \mathrm{~N}$ had a SWH "event" $\geq 2 \mathrm{~m}$. For SE3 SWH $H_{m 0}$, comparison between Station 2009N and 2009S generally showed a higher SWH for Station 2009S, with the exception of Station 2009 N which had a higher SWH during the "peak" wave state of SE3 (Fig. 22). Also, although Station 2009S did not have a SWH "event" $\geq 2 \mathrm{~m}$ during this period, Station 2009S SWH did peak over the $2 \mathrm{~m}$ threshold twice during this wave record. In addition, Station 2009S had a SWH "event" $\geq 1 \mathrm{~m}, 2009 \mathrm{~S}-1 \mathrm{~m}-16$ (Table 2).

For SE3 mean wave direction $\left(D_{m}\right)$, Station 2009 S generally experienced a more westerly wave direction than Station 2009N (Fig. 23), which instead exhibited southwesterly (Table 1) waves. An exception occurred when Station $2009 \mathrm{~N}$ wave direction was briefly more westerly than Station 2009S; this took place during a period of higher SWH for Station 2009S.

For SE4, Station 2009S was the main focus with a SWH "event" $\geq 2 \mathrm{~m}$. For SE4 SWH $H_{m 0}$, the comparison between Station $2009 \mathrm{~N}$ and $2009 \mathrm{~S}$ showed a much higher SWH for Station 2009S for half of the wave record (Fig. 24). For the other half of the wave record, Station 2009N SWH was seen to be at or slightly higher than Station 2009S SWH. Also, although Station 2009S did not have a SWH "event" $\geq 2 \mathrm{~m}$ during this period, Station 2009N SWH peaked over the $2 \mathrm{~m}$ threshold once briefly during this wave record. In addition, Station $2009 \mathrm{~N}$ had a SWH "event" $\geq 1 \mathrm{~m}, 2009 \mathrm{~N}-1 \mathrm{~m}-11$ (Table 1) for the entire wave record.

For SE4 mean wave direction $D_{m}$, Station $2009 \mathrm{~S}$ was at a more westerly wave direction than Station 2009N (Fig. 25), which was west-southwesterly (Table 2). This more westerly direction for Station 2009S was similar to what the wave record for SE3 showed.

For SE5, Station 2009S was the main focus with a SWH "event" $\geq 2 \mathrm{~m}$. For SE5 SWH $H_{m 0}$, the comparison between Station $2009 \mathrm{~N}$ and 2009S showed a much higher SWH for Station 2009S for the entire wave record (Fig. 26). Station 2009S's SWH was between 0.5 and $1.2 \mathrm{~m}$ higher than Station 2009N's SWH, a notable difference. However, Station $2009 \mathrm{~N}$ had a SWH "event" $\geq 1 \mathrm{~m}, 2009 \mathrm{~N}-1 \mathrm{~m}-15$ (Table 1) for part of the wave record, and peaked over the $2 \mathrm{~m}$ threshold once briefly during the wave record (Fig. 26). 
Station 2009S Directional Wave Spectrum

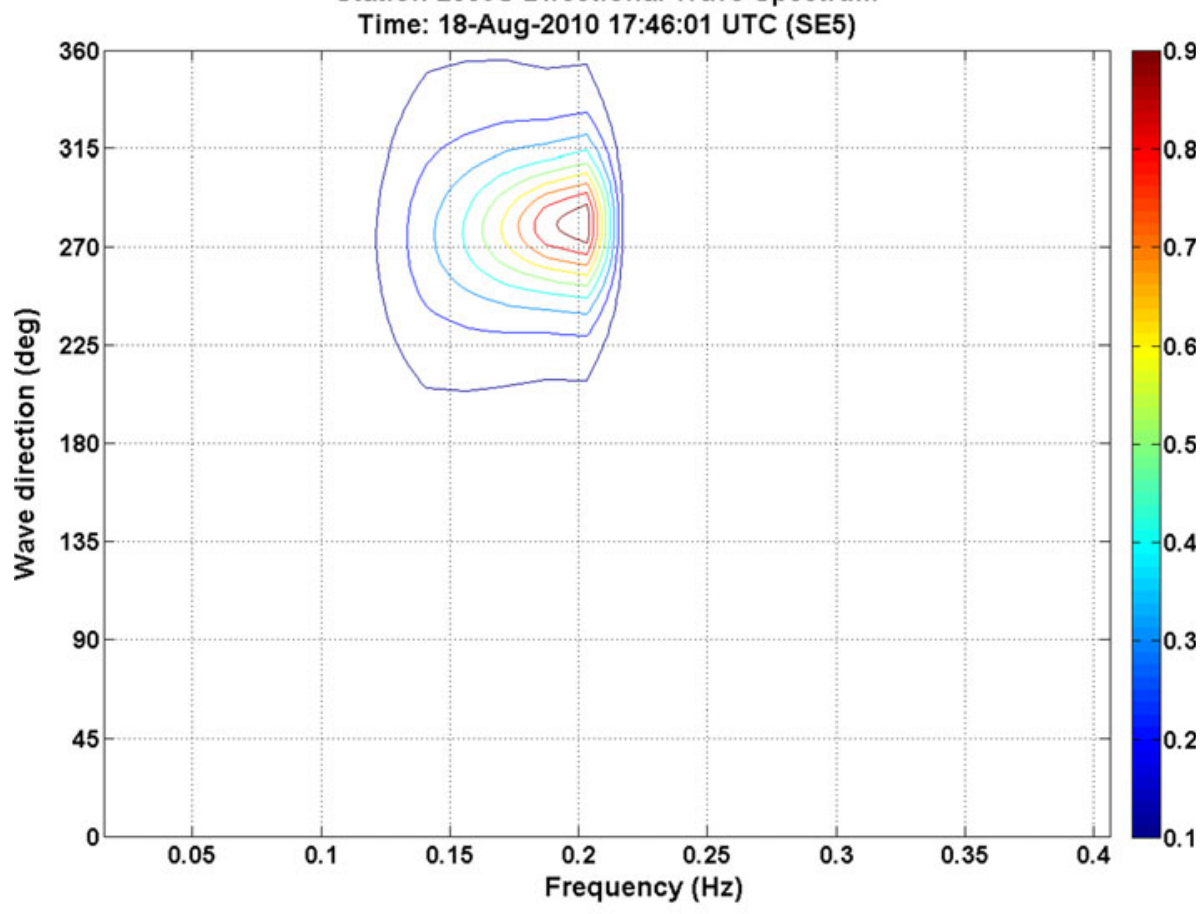

Station 2009S Non-Directional Wave Spectrum

Time: 18-Aug-2010 17:46:01 UTC (SE5)

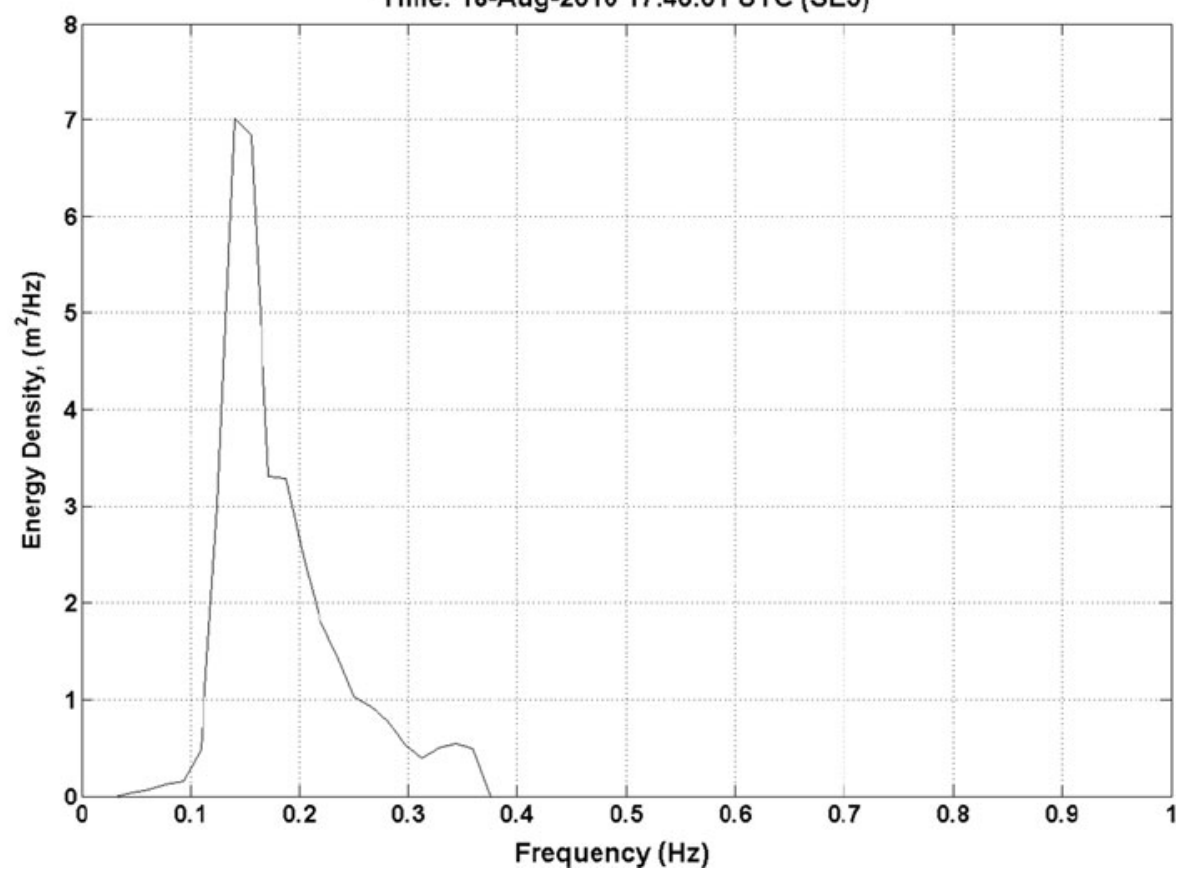




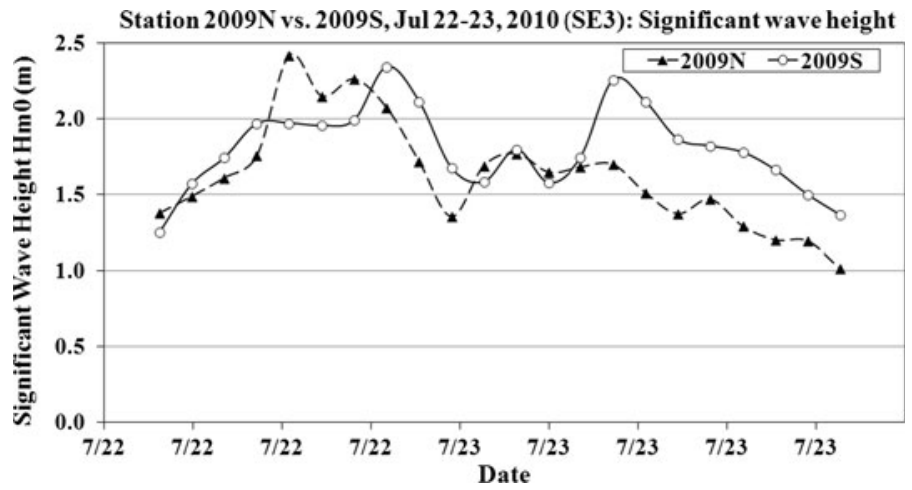

Fig. 22 SE3 significant wave height comparison. Comparison of recording Doppler current profiler (RDCP) significant wave height (SWH) during wave record July 22-23, 2010 (SE3) for two different Stations: (1) Station $2009 \mathrm{~N}, 67^{\circ} 38^{\prime} 17.76^{\prime \prime} \mathrm{N}, 164^{\circ} 20^{\prime} 46.26^{\prime \prime} \mathrm{W}$, north location near Kivalina, AK, water depth $17 \mathrm{~m}$, and (2) Station 2009S, 67 $10^{\prime} 33.30^{\prime \prime} \mathrm{N}, 163^{\circ} 59^{\prime} 23.94^{\prime \prime} \mathrm{W}$, south location near Cape Krusenstern, AK, water depth $18 \mathrm{~m}$

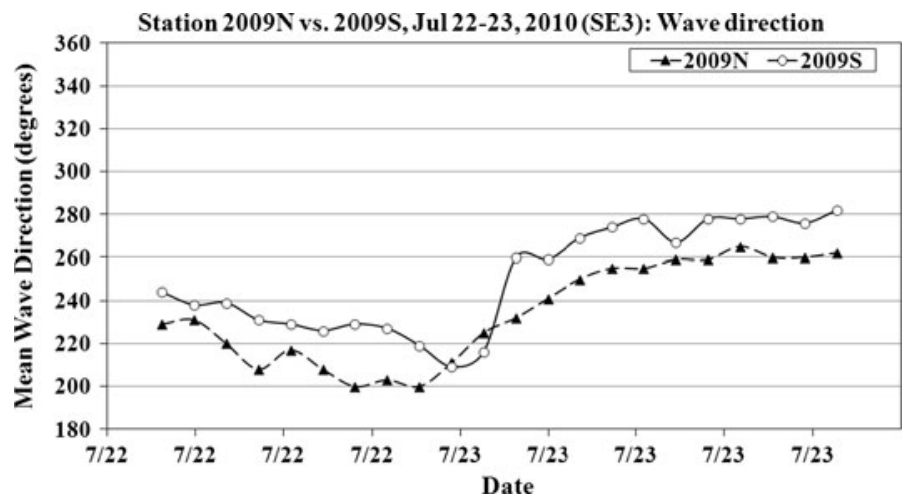

Fig. 23 SE3 wave direction comparison. Comparison of recording Doppler current profiler (RDCP) mean wave direction during wave record July 22-23, 2010 (SE3) for two different Stations: (1) Station 2009N, $67^{\circ} 38^{\prime} 17.76^{\prime \prime} \mathrm{N}, 164^{\circ} 20^{\prime} 46.26^{\prime \prime} \mathrm{W}$, north location near Kivalina, AK, water depth $17 \mathrm{~m}$, and (2) Station 2009S, $67^{\circ} 10^{\prime} 33.30^{\prime \prime} \mathrm{N}, 163^{\circ} 59^{\prime} 23.94^{\prime \prime} \mathrm{W}$, south location near Cape Krusenstern, AK, water depth $18 \mathrm{~m}$

For SE5 mean wave direction $D_{m}$, Station 2009S was situated west-northwesterly and Station 2009N was situated west-southwesterly (Fig. 27). Again, Station 2009S experienced waves coming from a less southerly direction.

\section{Discussion and conclusion}

From this study, significant wave heights at their highest (i.e. $\geq 2 \mathrm{~m}$ ) were chosen to determine whether these waves were swell or wind-sea. The results showed that the location of the RDCP Station determined the type of incoming waves. Wave direction was westerly, generally being $25^{\circ}$ to the north (clockwise) of the predominant southwest wind direction during two storm events, and $25^{\circ}$ to the south (counterclockwise) of the 


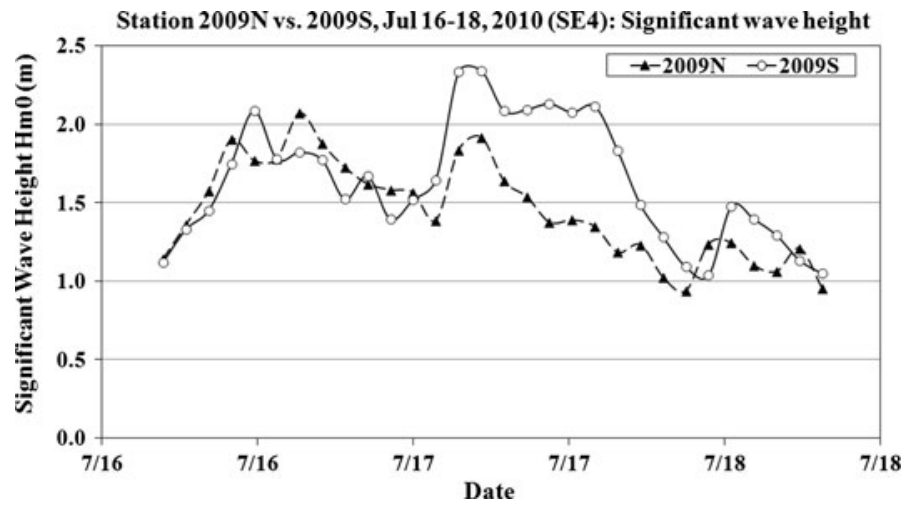

Fig. 24 SE4 significant wave height comparison. Comparison of recording Doppler current profiler (RDCP) significant wave height (SWH) during wave record July 16-18, 2010 (SE4) for two different Stations: (1) Station $2009 \mathrm{~N}, 67^{\circ} 38^{\prime} 17.76^{\prime \prime} \mathrm{N}, 164^{\circ} 20^{\prime} 46.26^{\prime \prime} \mathrm{W}$, north location near Kivalina, AK, water depth $17 \mathrm{~m}$, and (2) Station 2009S, $67^{\circ} 10^{\prime} 33.30^{\prime \prime} \mathrm{N}, 163^{\circ} 59^{\prime} 23.94^{\prime \prime} \mathrm{W}$, south location near Cape Krusenstern, AK, water depth $18 \mathrm{~m}$

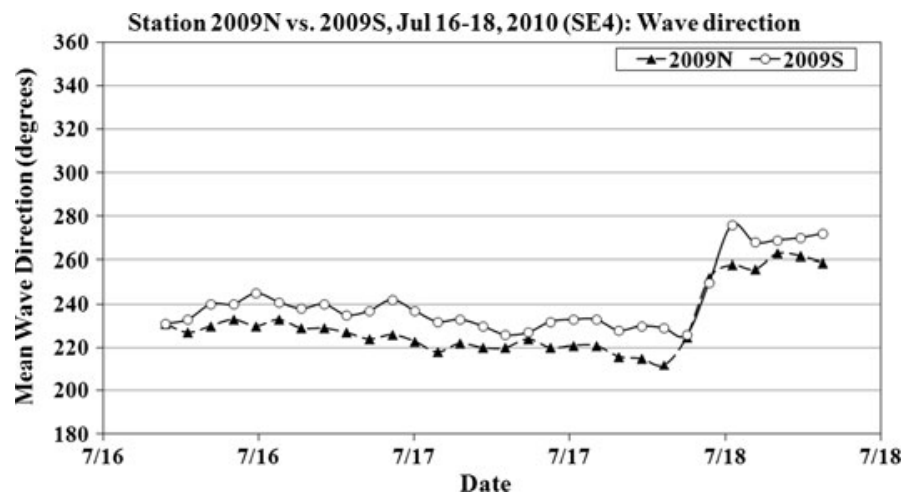

Fig. 25 SE4 wave direction comparison. Comparison of recording Doppler current profiler (RDCP) mean wave direction during wave record July 16-18, 2010 (SE4) for two different Stations: 1) Station 2009N, $67^{\circ} 38^{\prime} 17.76^{\prime \prime} \mathrm{N}, 164^{\circ} 20^{\prime} 46.26^{\prime \prime} \mathrm{W}$, north location near Kivalina, AK, water depth $17 \mathrm{~m}$, and (2) Station 2009S, $67^{\circ} 10^{\prime} 33.30^{\prime \prime} \mathrm{N}, 163^{\circ} 59^{\prime} 23.94^{\prime \prime} \mathrm{W}$, south location near Cape Krusenstern, AK, water depth $18 \mathrm{~m}$

predominant northwest wind direction during another storm event. The highest waves collected at the north Station (Station 2009N) were southerly "wind-sea". The highest waves collected at the south Station (Station 2009S) were westerly "swell".

Station 2009N displayed more south winds/waves compared with Station 2009S which had southwest to west-northwest winds/waves. A possible explanation for this would be wave refraction. There is a strong current prominent in the southeast Chukchi Sea region, traveling eastward and northward (Coachman and Tripp 1970; Overland and Roach 1987; Woodgate et al. 2005; Panteleev et al. 2010). At Station 2009S, this current is found to travel eastward and northward, which corresponds with the westerly and southwesterly wave direction. At Station 2009S, this current is found to travel northward, which corresponds with the southerly wave direction. Therefore, westerly waves that would have been present at Station $2009 \mathrm{~N}$ may have been refracted due to the strong current traveling northward. 


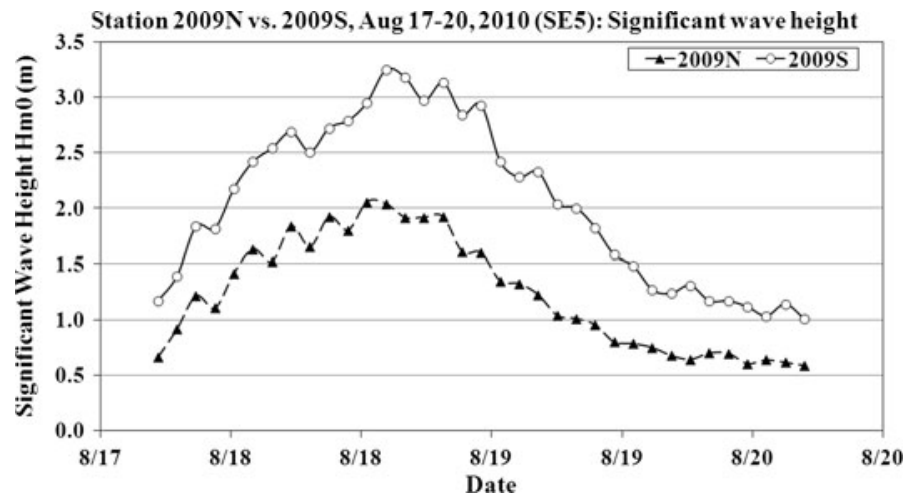

Fig. 26 SE5 significant wave height comparison. Comparison of recording Doppler current profiler (RDCP) significant wave height (SWH) during wave record August 17-20, 2010 (SE5) for two different Stations: (1) Station $2009 \mathrm{~N}, 67^{\circ} 38^{\prime} 17.76^{\prime \prime} \mathrm{N}, 164^{\circ} 20^{\prime} 46.26^{\prime \prime} \mathrm{W}$, north location near Kivalina, AK, water depth $17 \mathrm{~m}$, and (2) Station 2009S, 67 $10^{\prime} 33.30^{\prime \prime} \mathrm{N}, 163^{\circ} 59^{\prime} 23.94^{\prime \prime} \mathrm{W}$, south location near Cape Krusenstern, AK, water depth $18 \mathrm{~m}$

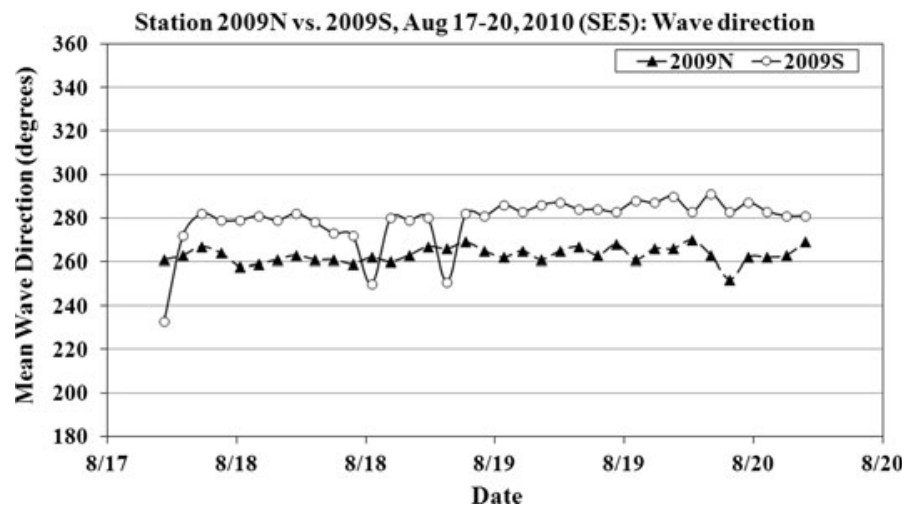

Fig. 27 SE5 wave direction comparison. Comparison of recording Doppler current profiler (RDCP) mean wave direction during wave record August 17-20, 2010 (SE5) for two different Stations: (1) Station 2009N, $67^{\circ} 38^{\prime} 17.76^{\prime \prime} \mathrm{N}, 164^{\circ} 20^{\prime} 46.26^{\prime \prime} \mathrm{W}$, north location near Kivalina, AK, water depth $17 \mathrm{~m}$, and (2) Station 2009S, $67^{\circ} 10^{\prime} 33.30^{\prime \prime} \mathrm{N}, 163^{\circ} 59^{\prime} 23.94^{\prime \prime} \mathrm{W}$, south location near Cape Krusenstern, AK, water depth $18 \mathrm{~m}$

The southerly wave direction at Station $2009 \mathrm{~N}$ may also be possible due to fetch. Station 2009N was positioned further north than Station 2009S and the greater fetch allowed south winds to propagate longer over the water creating south wind-sea as the highest SWHs. Wave direction for Station 2009S had more open westerly fetch for waves to propagate.

Station 2009N also exhibited SWHs that were smaller in magnitude and fewer in number than those recorded at Station 2009S (Tables 1,2). This was due to its proximity to an enclosed embayment north of Station 2009N, formed by the Point Hope promontory, sheltering it from northwesterly waves (Fig. 1). In addition, Station 2009N documented wind-sea compared with Station 2009S which experienced swell, due to the direction and magnitude of the winds. The Delong Mountain Terminal is positioned between Station $2009 \mathrm{~N}$ and 2009S, so it should expect to encounter both swell and wind-sea of greater than $2 \mathrm{~m}$ heights in the early open water season, with greater than $3 \mathrm{~m}$ swell heights. 
Besides current flow and fetch, shore-fast sea ice was also shown to play a role in wave activity. Although SST $<0^{\circ}$ from November 2009 to July 2010 (7-8 months), wave activity was dampened only during January to April 2010 (3 months) implying early ice breakup in this nearshore region. This early ice breakup is thought to be caused by extratropical cyclonic activity later and earlier in the seasons (Sienkiewicz et al. 2005), and less available sea ice (Comiso et al. 2008).

Low pressure systems and neighboring high pressure systems that last for several days are the primary cause of high wind speeds over the southern Chukchi Sea that force the wave states observed during the three SWH events selected for this study. Low pressure systems converging over the eastern Chukchi Sea for SE3 and SE4 produced strong southwesterly winds over the southeast Chukchi Sea. A low pressure system over the Brooks Range in northern Alaska for SE5 produced strong northwesterly winds over the southeast Chukchi Sea. For SE3 and SE5, these storms took the form of a strong cyclonic pattern. For SE4, the cyclonic pattern was weaker.

The wave state potential for this region has been demonstrated to be capable of supporting a SWH of $3 \mathrm{~m}$ and extended periods of greater than $2 \mathrm{~m} \mathrm{SWH}$. A westerly wave direction implies that the main shipping route through the Bering Strait is susceptible to a direct influence from these waves. Users of this area currently affected include Coast Guard vessels, oil lease support vessels and drilling activity, the bulk carriers that connect with the Teck Alaska Inc. Delong Mountain Terminal, small craft from coastal communities, and the ever-increasing traffic around the Arctic that is spurred on by sea ice decline. Any developers of off-shore structures, such as jack-up rigs or artificial production islands, must factor sea-states of at least this magnitude into design considerations and must assume that they will occur annually given the frequency of storms that occur in the Chukchi Sea region.

This study also demonstrates that early-season westerly winds are able to cause the highest wave events for the study period in this region. These are caused by northern storms during the non-stormy period of the summertime (July-August) in contrast to southeasterlies/southerlies from Bering Sea lows in the later fall. Although these wave heights may not hamper heavy shipping traffic, these types of waves/winds could affect small craft and contribute to coastal erosion and sediment transport. In addition, this study suggests that the Delong Mountain Terminal port site may experience the need for continuous dredging, due to these types of south and west wave events.

Acknowledgments This publication is the result in part of research sponsored by the Cooperative Institute for Arctic Research (CIFAR) with funds from the National Oceanic and Atmospheric Administration (NOAA) under cooperative agreement NA17RJ1224 with the University of Alaska. Funding also provided by NOAA projects, NA06OAR4600179 and NA08OAR4600856. Generous logistical support from Teck Alaska Incorporated and Foss Maritime Company has been provided to this project from its beginning.

Open Access This article is distributed under the terms of the Creative Commons Attribution License which permits any use, distribution, and reproduction in any medium, provided the original author(s) and the source are credited.

\section{References}

AADI (Aanderaa Data Instruments) (2006) RDCP primer TD 220c, $70 \mathrm{pp}$

Coachman LK, Tripp RB (1970) Currents north of bering strait in winter. Limnol Oceanogr 15(4):625-632

Comiso JC, Parkinson CL, Gersten R, Stock L (2008) Accelerated decline in the Arctic sea ice cover. Geophys Res Lett 35. doi:10.1029/2007GL031972 
Ewing JA (1980) Observations of wind-waves and swell at an exposed coastal location. Estuar Coast Marine Sci 10:543-554

Francis OP, Atkinson DE (2012) Synoptic forcing of wave states in the southeast Chukchi Sea, Alaska, at an offshore location. Nat Hazards (in press). doi:10.1007/s11069-012-0142-4

Francis-Chythlook O (2004) Coastal processes in Elson Lagoon, Barrow, Alaska. MS Thesis, University of Alaska Anchorage, Anchorage

Hudak DR, Young JMC (2002) Storm climatology of the southern Beaufort Sea. Atmosphere Ocean 40:145-158

Kistler R, Kalnay E, Collins W, Saha S, White G, Woollen J, Chelliah M, Ebisuzaki W, Kanamitsu M, Kousky V, van den Dool H, Jenne R, Fiorino M (2001) The NCEP-NCAR 50-year reanalysis: monthly means CD-ROM and documentation. Bull Amer Meteor Soc 82:247-267

Mesinger F, DiMego G, Kalnay E, Mitchell K, Shafran PC, Ebisuzaki W, Jovic D, Woollen J, Rogers E, Berbery EH, Ek MB, Fan Y, Grumbine R, Higgins W, Li H, Lin Y, Manikin G, Parrish D and Shi W (2006) North American regional reanalysis. Boulder, CO NOAA.OAR/ESRL PSD:42

Overland JE, Roach AT (1987) Northward flow in the Bering and Chukchi Seas. J Geophys Res 92(C7):7097-7105

Panteleev G, Nechaev DA, Proshutinsky A, Woodgate R, Zhang J (2010) Reconstruction and analysis of the Chukchi Sea circulation in 1990-1991. J Geophys Res 115:C08023. doi:10.1029/2009JC005453

Sienkiewicz JM, Von Ahn JM, McFadden GM (2005) Hurricane force extratropical cyclones. Am Meteorol Soc

WMO (World Meteorological Organization) (1998) Guide to wave analysis and forecasting, 2nd edn. WMO-No. 702, Secretariat of the World Meteorological Organization-Geneva Switzerland. ISBN 92-63-12702-6

Woodgate RA, Aagaard K, Weingartner T (2005) A year in the physical oceanography of the Chukchi Sea: Moored measurements from autumn 1990-91. Deep Sea Res II 52(24-26):3116-3149 